\title{
Globalização em debate
}

\author{
Erros de planejamento
}

Afonso C. Fleury (EP-USP) - O texto apresentado pelo professor Jacob Gorender é extremamente instigante por tratar questões relativas à globalização a partir de perspectivas bastante diversificadas, com uma abordagem integrativa que provoca diversas reflexões. Algumas inquietações podem ser suscitadas a partir do texto. Comecemos com o caso da Metal Leve, uma espécie de simbolização de todas as dimensões envolvidas na globalização. Por tudo que representa na história industrial e tecnológica do Brasil, a Metal Leve é um ponto de reflexão para nós. Essa empresa já foi um símbolo de sofisticação tecnológica, de auto-suficiência, de capacidade empresarial autonomamente definida. É difícil de aceitar o que, há pouco, se passou com ela. Dessa forma, torna-se extremamente importante tentar compreender o que se esconde por trás de sua história e passar para um plano maior de análise e reflexão.

Duas questões específicas do processo industrial brasileiro merecem ser destacadas. Em primeiro lugar, uma série de decisões estratégicas e políticas tomadas na década de 50 parece hoje ter chegado ao fim. Em segundo, faz-se necessário questionar o que realmente aconteceu durante esse período em termos de planejamento, já que é a partir da história que poderá ser feita uma redefinição sobre o período atual de industrialização do Brasil para ser possível aprender com o passado.

Do ponto de vista das decisões estratégicas ocorridas no país, existem duas questões fundamentais, que estão na base de qualquer discussão sobre o atual parque industrial brasileiro. A primeira delas é básica para entender o processo de industrialização dependente que caracteriza o Brasil: a partir da década de 50, o país viveu um momento de industrialização acelerada, os cinqüenta anos em cinco. Entretanto, esse processo de industrialização baseouse em empresas multinacionais, abrangendo as indústrias mais dinâmicas e as de alta tecnologia.

Como segunda questão a ser colocada, durante esse período não houve no país um processo de substituição de importações, mas de reprodução de importações, ou seja, produzia-se aqui aquilo que era produzido no exterior, com raros desenvolvimentos específicos para o contexto brasileiro. A cópia de modelos forâneos não foi feita apenas em termos de produtos industriais. $\mathrm{O}$ mesmo ocorreu em termos de modelos de gestão. Raramente, o conhecimento era absorvido para, então, ser reorganizado e, com ele, avançar-se em direção a modelos mais adequados à realidade brasileira.

PLANEJAMENTO - Em termos políticos, pode-se dizer que já houve diversas atividades de planejamento no Brasil. Mas é o próprio processo de planejamento que deve ser pensado. Muitas vezes, tais atividades são mal dimensionadas e existem alguns exemplos desse fato na história brasileira, como a questão dos grandes projetos de infra-estrutura desenvolvidos durante os governos militares. Algumas empresas têm projetos gigantescos, absolutamente desproporcionais em termos de suas possibilidades. Uma das empresas de Araraquara - a Cobrasma - foi projetada com capacidade produtiva para fabricar 120 locomotivas/ano. Entretanto, sua produção nunca passou de cem locomotivas/ano. Na área de informática, planejou-se mal ao tentar produzir de tudo, do software ao comando numérico. Enquanto o Japão, então uma pequena potência industrial, possuía duas empresas de comando numérico, o Brasil possuía 16. 
Outro problema a ser destacado é a ausência de política industrial, o que faz com que o setor seja sempre dependente da política econômica - muitas vezes de maneira até ilógica. Após o plano Cruzado, por exemplo, pôde-se observar imenso desgaste da rede de fornecimento na indústria nacional motivado por oscilações econômicas. Isso gerou um processo de dificuldades nas negociações de preços dentro da cadeia produtiva, fazendo com que todas as relações de confiança existentes antes da implantação do plano acabassem. Essas relações precisaram ser construídas novamente, em outros moldes. Pode-se dizer que processo semelhante vem ocorrendo na indústria automobilística.

Outro aspecto importante é que, muitas vezes, planeja-se, mas o planejamento não é levado adiante. Algumas políticas industriais e de planejamento foram feitas e, em seguida, abandonadas. A política de informática é uma delas. A lógica utilizada a partir de 1977 para capacitação nacional em informática, baseada nos microcomputadores, é outra. Em 1982, a lógica prevalecente foi abandonada e começou-se a planejar tudo novamente, desconsiderando o que havia sido decidido a partir da década de 70 . Tal procedimento gerou desconforto e trauma num campo por si só muito complexo.

Além dos aspectos já mencionados, o Brasil ainda não entendeu - ou não quer entender - as regras do comércio internacional. Como exemplo claro desse fato pode-se citar que, por volta de 1982 - época de ápice da crise da dívida externa -, o ministério da Fazenda instituiu a campanha Exportar é o que importa. As indústrias começaram a exportar todo tipo de produtos sem a menor preocupação com a qualidade, desgastando a imagem dos produtos made in Brazil. Muitos problemas com produtos brasileiros exportados ocorreram não apenas em países desenvolvidos, mas também em países latinos ou africanos. Atualmente, há tantas empresas tentando conquistar o ISO 9000 justamente porque a tarja made in Brazil não as ajuda; pelo contrário, as atrapalha. Portanto, se o produto contiver o ISO 9000 no lugar do made in Brazil, terá maiores chances no mercado internacional.

Finalmente, o Brasil ainda não criou competências locais que permitissem um relacionamento mais equilibrado com o contexto da globalização. Chegou a esse momento de globalização extremamente vulnerável. Como apresentado no texto de Jacob Gorender, há três ondas ocorrendo no mundo: a da automação da tecnologia informática, a da racionalização do modelo japonês e a da globalização. Os países, que conseguiram antever e entrar nessas onda, surfaram de modo relativamente fácil, conseguindo se manter adequadamente. Com a abertura das importações, em 1990, as três ondas invadiram o Brasil ao mesmo tempo e, hoje, o país luta para não se afogar devido à enorme dificuldade que tem em planejar, antecipar e prever, regras primeiras na concepção de um processo mais globalizado.

O momento atual, de corrida desenfreada atrás de empregos - envolvendo, inclusive, a questão da tão discutida guerra social -, parece extremamente importante. Trata-se de uma reação imediatista para gerar empregos hoje e não se sabe muito bem como será a criação de empregos no futuro.

A atual volatilidade do mercado financeiro, ou seja, dos capitais circulando livremente no mundo, está se reconfigurando em processo produtivo. Devido à dinâmica produtiva e ao ciclo dos produtos cada vez mais curto, há um sistema de produção deslocando-se em torno do mundo, com velocidade crescente, tornando a própria base produtiva muito mais volátil. Na medida que há dependência cada vez maior das empresas internacionais, fica-se cada vez mais vulnerável. O fundamental, como afirma o professor Gorender, é estabelecer os critérios e funções para que realmente o capital multinacional possa ser incorporado, mas, ao mesmo tempo, possamos resguardar uma situação favorável ao Brasil. Oferecem-se 15 anos de benefícios para empresas estrangeiras que se instalem no país, mas sabe-se que nenhuma delas pretende aqui ficar mais do que 15 anos, como tem acontecido em vários outros lugares, principalmente na Ásia. Provavelmente, na hora de pagar a conta, tais empre- 
sas nem estarão mais aqui para assinar o recibo. É preciso pensar rapidamente sobre tais questões, caso contrário, o emprego de hoje vai se tornar o desemprego de amanhã.

\section{A necessidade de um projeto nacional}

Hélio Zilberstajn (FEAC-USP) - Para enfrentar a situação provocada pela globalização é preciso, antes de tudo, um projeto nacional. O texto apresentado por Jacob Gorender não explicita a questão nesses termos, mas deixa tal aspecto subentendido ao enfatizar, por exemplo, a busca da competitividade sistêmica. Como vemos no texto, a competitividade sistêmica depende de uma série de fatores, como: política monetária e, portanto, econômica; infraestrutura; regulação; despesas de consumidores; questão ambiental; aspectos institucional e político; planejamento; impostos e tarifas; fatores sociais.

Além disso, há outro fator muito importante na busca da competitividade sistêmica: a existência de um sistema eficiente de poupança nacional. A capacidade que se tenha de poupar, de direcionar tal poupança para investimentos a longo prazo, é parte fundamental desse projeto. Ao tratar a questão da competitividade sistêmica, Gorender relativiza alguns aspectos, como o que envolve a questão dos encargos sociais. De acordo com ele, os encargos sociais são uma questão irrelevante, subordinada à questão da competitividade sistêmica. Entretanto, talvez essa não seja uma questão tão irrelevante assim.

No texto de Gorender, há alguns pontos contraditórios: por exemplo, em alguns momentos o custo de trabalho é colocado como irrelevante para a competitividade sistêmica, mas, em outros, torna-se relevante, como ocorre quando é mencionado o caso das maquiladoras no México (no texto, são também abordados outros países da América Latina). As maquiladoras atraem as empresas norte-americanas para desenvolver uma fase da produção do lado mexicano da fronteira e, depois, esses produtos voltam para o lado norteamericano, exatamente em função da abundância e do baixíssimo preço do trabalho no México. Assim, a questão do custo de trabalho - seja ele alto ou baixo - tem alguma relevância com relação à competitividade sistêmica.

A questão da globalização e o desemprego estrutural por ela agravado tornam fundamental a necessidade de um projeto nacional. Faz-se necessário olhar com muita atenção a questão da proteção social, já que é evidente nem todos os brasileiros terem capacidade de se ajustar a essa nova realidade, ou seja, muitos brasileiros não têm empregabilidade. O que fazer, então? A redefinição total da política de proteção social brasileira é urgente. A globalização, mais do que nunca, mostrou a importância dessa redefinição.

$\mathrm{Na}$ estrutura de encargos sociais do Brasil, grande parte deles financia a previdência social. Apenas para o INSS, a folha de salários é hoje onerada em $32 \%$. Entretanto, para oferecer o plano de benefícios do INss seriam necessários apenas 13\%. Há uma sobrecarga de aproximadamente $20 \%$, a qual não é apenas um problema de gestão ou de corrupção; é um problema do próprio modelo, que financia os excluídos com o recolhimento das contribuições dos que estão no mercado formal. Esse é o nosso modelo de proteção social: basicamente, busca-se o financiamento no emprego, e isso acaba onerando os custos com o trabalho. É urgente, portanto, repensarmos o projeto de proteção social do Brasil.

\section{A ideologia da globalização}

Paulo Nogueira Batista Jr. (IEA-USP) - O texto apresentado por Jacob Gorender constitui uma contribuição relevante para o debate sobre as tendências internacionais, a evolução tecnológica e o mercado de trabalho. Alguns aspectos do trabalho, notadamente aqueles que se relacionam à momentosa questão da "globalização", serão comentados a seguir. 
Gorender ressalta, com razão, que "globalização" é uma nova palavra para o antigo processo de internacionalização e de criação de um mercado de alcance mundial, processo que remonta à expansão da civilização européia a partir do final do século Xv. Como lembra o historiador Marc Ferro (1996:395), o processo de unificação do mercado mundial foi lançado pela colonização, resultando em ampliação das desigualdades entre os países colonizadores e os demais. Caberia até indagar se a chamada globalização, que tanto entusiasmo suscita em certos círculos, não é a continuação da colonização por outros meios...

Gorender observa que a ideologia da globalização está impregnada do discurso sobre as virtudes ecumênicas da competição e do mercado livre. Não há dúvida. Os últimos 20 anos têm sido marcados por um movimento regressivo, de restauração do ideário econômico do século XIX, e pelo predomínio de certas vertentes da teoria econômica que repelem toda, ou quase toda, intervenção do Estado como nociva ao funcionamento espontâneo do mercado. A ideologia da globalização, em especial a idéia de que a internacionalização crescente dos mercados estaria levando ao declínio irreversível do Estado, é um desdobramento do pensamento "neoliberal".

Mas é notável o contraste entre esse discurso ideológico, que muitos compram pelo valor de face, e as práticas concretas dos Estados nacionais dos países desenvolvidos. Como grande parte da discussão, até mesmo nos meios acadêmicos, se dá em nível puramente doutrinário, tal contraste não tem recebido a devida atenção.

De forma geral, o nível do debate no Brasil tem sido deplorável. Reina a adesão servil aos modismos internacionais. Poucos procuram verificar o que de fato está acontecendo e as controvérsias adquirem, muitas vezes, caráter artificial e até surrealista. Os porta-vozes do "neoliberalismo"e da "globalização" pregam a aplicação de políticas e modelos não seguidos pelos países nos quais essas ideologias têm origem. Enquanto isso, a esquerda investe contra moinhos de vento, ou se deixa intimidar pela propaganda ideológica dominante.

No entanto, não é necessário grande esforço para perceber as falácias do discurso hegemônico. Basta consultar, por exemplo, os números publicados por organizações internacionais como OCDE e FMI. Quem se der ao trabalho de fazê-lo, verá que nos anos 80 e na primeira metade da década de 90 , em plena época de suposto triunfo do assim chamado neoliberalismo, a participação do Estado na economia não se reduziu nos países mais adiantados. Ao contrário, aumentou em quase todos eles: aumentou a participação do gasto público no PIB; aumentou a carga tributária; aumentou também a dívida pública como proporção do PIB e a participação do emprego público no emprego total.

A obsolescência do Estado nacional, pelo menos no que se refere aos países mais adiantados, é uma fantasia inventada e propagada para uso de incautos.

ESTADOS NACIONAIS - É certo que houve desregulamentação de mercados, de alguns segmentos do sistema financeiro, programas importantes de privatização, etc. Mas a participação do Estado na economia, que já vinha crescendo expressivamente e de forma mais ou menos contínua ao longo de todo o século xx, continuou a aumentar no período mais recente, a despeito da preponderância ideológica do pensamento "neoliberal".

É o que revela, por exemplo, a maioria dos indicadores agregados publicados periodicamente pela OCDE. Nos Estados Unidos e no Japão, o gasto público total passou de 31\% do PIB em 1978-81 para 34\% em 1992-95; na Alemanha, de 48\% para 49\%; no G-7, que inclui, além dos três países já citados, o Canadá, a França, a Itália e o Reino Unido, a média ponderada da relação gasto público/PIB aumentou de 36\% para 40\% nesse período (1).

Aumentou, também, a carga tributária, definida como a relação entre a receita corrente do governo (inclusive governos estaduais e locais) e o PIB. Nos EUA, passou de $30 \% \mathrm{em}$ 
1978-81 para 31\% em 1992-95; no Japão, de 27\% para 32\%; na Alemanha, de $45 \%$ para 46\%; no $\mathrm{G}-7$, de $33 \%$ para $36 \%(2)$.

No mesmo período, cresceu substancialmente o endividamento do setor público. Nos países do G-7, a dívida pública bruta passou de 42\% do PIB em 1978-81 para 68\% em 1992-95. Em termos líquidos, o endividamento governamental dobrou no mesmo período, passando de $21 \%$ para $42 \%$ do PIB (3).

Dados semelhantes foram apresentados em relatório recente do Fundo Monetário Internacional - outra fonte insuspeita de preferências estatizantes. O FMI atribui o aumento da carga tributária, observado "em quase todos os países desenvolvidos nas décadas recentes", ao aumento das contribuições sociais e a "impostos diretos mais altos - muitas vezes via alíquotas marginais elevadas" (4). O crescimento dos déficits e do endividamento públicos nesses países é explicado basicamente por aumento ainda maior nas despesas públicas, de uma média simples de 28\% do PIB em 1960 para 50\% em 1994 (5).

No plano da política de comércio exterior, também é notável a distância entre retórica e realidade. O economista Robert Wade (1996:69), da Universidade de Sussex, observa que enquanto as barreiras comerciais vêm descendo no Sul, o movimento no Norte tem sido na direção oposta. Das 24 economias integrantes da OCDE, apenas quatro (Japão, Austrália, Nova Zelândia e Turquia) reduziram obstáculos ao comércio ao longo dos anos 80 . As outras 20 vêm estabelecendo novas barreiras na forma de quotas, restrições comerciais "voluntá-rias" e comércio administrado.

Quanto ao emprego público, dados da ocDE, reproduzidos na revista The Economist, também projetam imagem algo diferente da que estamos acostumados a receber. Num conjunto de 15 países desenvolvidos (que inclui o G-7, mais sete outros países europeus e a Austrália), 13 registraram aumento da participação do emprego público no emprego total entre 1970 e 1994. Só nos EUA e na Inglaterra houve queda nessa participação, e apenas no segundo caso foi significativa (6).

Mesmo no campo financeiro, no qual mais avançou o processo de internacionalização, o papel do Estado continua crucial. O funcionamento dos mercados financeiros "globais" continua dependendo decisivamente da atuação dos Estados nacionais no campo regulatório ou como emprestadores de última instância em momentos de crise financeira. Recorde-se, por exemplo, a mega-intervenção comandada pelo governo dos EUA por ocasião do pânico financeiro mexicano no início de 1995. O Estado nacional dos EUA, velho de guerra, veio em socorro dos mercados financeiros e dos investidores norte-americanos, mobilizando dezenas de bilhões de dólares com a ajuda do FMI. Conseguiu conter a propagação da crise e, evidentemente, ninguém reclamou.

O MITO DAS TRANSNACIONAIS - Outro ponto importante do trabalho de Gorender é a distinção conceitual entre empresas multinacionais e empresas transnacionais. Tem razão ao dizer que o termo "empresa transnacional" não é aplicável, se entendido como sugere a expressão, isto é, designando empresa que transcenderia o âmbito nacional e que não teria base ou dependência na-cional.

Como observa Gorender, as grandes corporações não se desgarram, em geral, dos Estados nacionais nos quais têm origem. Constituem, ao contrário, uma questão de política internacional para esses Estados. Quem tiver dúvidas sobre este ponto que recorde, por exemplo, a atuação do governo norte-americano no episódio recente do Sivam.

Não há dúvida que nas últimas décadas aumentou a proporção de firmas que operam em âmbito internacional. A maioria das corporações industriais e financeiras dos países desenvolvidos mantém parte dos seus ativos produtivos no exterior. 
Daí não segue, entretanto, que se possa falar no predomínio de empresas "transnacionais" ou "globalizadas". Corporações verdadeiramente transnacionais são raras. A maior parte delas são empresas de base nacional. E não há tendência perceptível de predomínio de empresas genuinamente globais.

Uma corporação transnacional, como indica a palavra, não teria identificação nacional específica. Em livro recente, dois acadêmicos ingleses, Paul Hirst \& Grahame Thompson (1996: 1-17, 76-98), ressaltam que tal noção não se coaduna com o comportamento efetivo das grandes empresas. As corporações tendem a realizar funções centrais, como pesquisa e desenvolvimento, em seu país de origem. As atividades geradoras de maior valor adicionado também tendem a se concentrar na base nacional da empresa. Mais correto é falar em empresas internacionais ou multinacionais de base japonesa, alemã, norte-americana etc. Empresas de base nacional, ainda que orientadas para o mercado internacional.

Na verdade, há muito exagero quanto ao alcance do processo de internacionalização em curso no campo empresarial. Muitas análises baseiam-se em dados inadequados. Não basta, por exemplo, considerar os fluxos de entradas e saídas de investimentos diretos registrados nas contas de capitais dos balanços de pagamentos. Esses mostram, de fato, crescimento extraordinário nas décadas recentes. É preciso, porém, avaliar o peso relativo da atividade doméstica e da atividade internacional das grandes empresas: comparar as vendas externas com as internas, verificar o percentual dos ativos que essas empresas mantêm no exterior, confrontar os lucros gerados domesticamente com os lucros gerados por subsidiárias e afiliadas no exterior, entre outros aspectos.

Dados levantados por Hirst \& Thompson (1996:80-98) indicam que a base doméstica continua sendo o centro das atividades das empresas internacionais dos principais países desenvolvidos. Algo como 70 a $75 \%$ do valor adicionado é produzido no país de origem das corporações. No caso do setor industrial norte-americano, dados levantados por L. Tyson (apresentados em trabalho cujo sugestivo título é They are not us: why American ownership still matters) indicam que operações na matriz nos EUA respondiam por $78 \%$ dos ativos totais, $70 \%$ das vendas totais e 70\% do emprego total das multinacionais do país em 1988 (7).

PESQUISA E DESENVOLVIMENTO - O quadro é semelhante para as atividades tecnológicas e de pesquisa e desenvolvimento. Hirst \& Thompson estimam que apenas 10 a $30 \%$ da atividade tecnológica das empresas internacionais acontecem em subsidiárias estrangeiras (8). Pesquisa anterior, de Pari Patel \& Keith Pavitt (1991:1-21) da Universidade de Sussex, já mostrara que as grandes empresas concentram as suas atividades de pesquisa e desenvolvimento nas suas bases nacionais. As firmas das principais economias do mundo - Alemanha, Japão e EUA - realizam menos de $15 \%$ da sua atividade tecnológica fora do país de origem. A produção de tecnologia, concluem os autores, constitui um caso importante de "nãoglobalização".

É certo que a tendência à integração dos mercados nacionais, especialmente no campo das finanças, cria situações novas e novos desafios. Como observa Gorender, os meios de intervenção do Estado já não são os mesmos. Mas, no debate brasileiro, nem sempre se destacam os aspectos mais relevantes dessa alteração nas possibilidades de intervenção do Estado.

Uma das limitações mais sérias associadas à integração crescente dos mercados financeiros, e em especial ao volume crescente de ativos líquidos e voláteis, é a dificuldade crescente de sustentar regimes cambiais como o que vigora no Brasil desde fins de 1994. Como ressaltou Barry Eichengreen (1994), em livro sobre as tendências dos arranjos monetários internacionais, a enorme ampliação dos fluxos internacionais de capital torna cada vez mais difícil administrar regimes de ancoragem cambial, especialmente os sistemas de câmbio fixo 
ajustável, como o que existiu na Europa até a crise cambial de 1992-93, o do México até a crise de 1994, e o que vigora atualmente no Brasil.

Enfim, toda essa discussão está sendo, a meu ver, mal conduzida. O trabalho de Jacob Gorender representa contribuição significativa para um debate mais esclarecedor. Num país como o Brasil, onde quase ninguém dá atenção ao que acontece no resto do mundo e o onde debate sobre questões internacionais se reduz, em geral, à mera reprodução dos mais surrados chavões, estudos como esse são sempre de grande valia.

\section{Repercussão do processo na classe trabalhadora}

Ricardo Antunes (Unicamp) - Quero, nesta exposição, indicar de que modo as transformações vividas atualmente no processo de reestruturação produtiva do capital repercutem no universo da classe trabalhadora, acentuando alguns traços críticos que vêm afetando fortemente o mundo do trabalho.

Em primeiro lugar, a reestruturação produtiva, que se configura após mea-dos dos anos 70 com suas variadas formas de flexibilização e desregulamentação, acarreta transformações radicais no interior do processo produtivo, do processo fabril e também do setor de serviços. Essas transformações têm como conseqüên-cia mais forte, direta e violenta, um conjunto de mutações que fazem aflorar com muita intensidade seus traços destrutivos.

Entre os traços destrutivos das transformações ocorridas no mundo do trabalho temse a gestação de formas muito acentuadas de trabalho precarizado, podendo o desemprego ser colocado como o outro lado da questão, em escala muito acentuada e abrangente. Em diversas partes do mundo, a constatação mais evidente, ao observar tais transformações no mundo do trabalho, é a percepção, por um lado, de um conjunto muito fragmentado de trabalhadores com direitos precarizados e, por outro, do desemprego em escala abrangente. Paralelamente - e como se trata de um processo que fraciona muito fortemente a classe trabalhadora -, há também a tendência de ocorrência de setores mais qualificados, devido à aparência de um quadro positivo entre os trabalhadores que conseguem manter seus trabalhos e empregos. Esta tendência, porém, afeta parcela muito menor dos trabalhadores, quando comparada ao contingente de precarização dos desempregados. Tais transformações - ao contrário do que muitos têm dito - não acarretam de forma alguma o fim do trabalho, do proletariado, da classe trabalhadora, mas têm como resultado um conjunto de mudanças de sentido contraditório, sem uma única conseqüência direta, clara e linear a ponto de se poder afirmar que o trabalho ou a classe trabalhadora esteja desaparecendo. Tal tese tem conquistado muitos adeptos, propagada às vezes pela própria imprensa, por seu impacto enquanto manifestação de tendência ao desemprego em escala muito ampliada.

Ao indagar o que se passa no mundo do trabalho nesse contexto de mundialização do capital, algumas tendências podem ser apontadas. É importante lembrar que o atual quadro vem se desenhando desde os anos 70 com a crise do taylorismo, do fordismo e com o advento, no interior do capitalismo, de diversas formas de produção de mercadorias com evidentes traços distintivos. Com relação ao fordismo, o fator de maior impacto junto às classes trabalhadoras foi o chamado modelo toyotista, e a forma pela qual ele se ocidentalizou. Por modelo toyotista, deve-se entender elementos mais ou menos descaracterizados do modelo japonês introduzidos no Ocidente.

MODELO JAPONÊS - O ideário que marca atualmente a fala dominante no mundo empresarial - o just in time, o kanban, o processo de qualidade total, entre outros -, tem sua origem no processo que nasceu na Toyota, não hoje, nem mesmo nos anos 70, mas no imediato pós-guerra, passando por um período de constituição e de consolidação. Entretanto, há um claro descompasso entre o toyotismo no Japão e a sua ocidentalização. Um dos 
traços constitutivos do toyotismo do Japão não implantado no Ocidente é o emprego vitalício para a parcela mais qualificada das classes trabalhadoras. Não conheço qualquer empresa que tenha mencionado esse privilégio dado aos trabalhadores japoneses entre os elementos da qualidade total.

Com a ocidentalização do experimento japonês, e com a reciclagem ocorrida nas indústrias norte-americanas e em países europeus ao assimilar o modelo, o Japão perdeu as vantagens que havia obtido no terreno da competitividade, vendo-se em situação mais difícil que se manifesta em sua crise atual. No Japão já se fala, há pelo menos dois ou três anos, em eliminar o emprego vitalício, um dos pilares constitutivos do modelo japonês. Quem acompanha esses debates pode perceber que os próprios níveis de desemprego no Japão - mesmo os oficiais - já não podem ser considerados como inexistentes.

Nesse cenário de mundialização, num primeiro momento o Japão concentrou-se em seu mercado interno, expandiu-se, consolidou-se; posteriormente, seu capital voltou-se para o mundo e seu experimento foi mais ou menos assimilado. Nessa mundialização, tais experimentos acabaram por aumentar o índice de competitividade das indústrias em vários países do Ocidente, resultando na precarização mais acentuada do próprio trabalhador japonês.

No mundo ocidental, portanto, a primeira tendência a ser apontada é a redução acentuada do operariado manual fabril estável, daquele operário de massa, na expressão consagrada pelos italianos. Esse quadro de operários estáveis vem sendo reduzido. A redução dos trabalhadores em empresas do $\mathrm{ABC}$, de todo núcleo industrial brasileiro e de tantos parques industriais em tantas partes do mundo, confirma tal tendência. Entretanto, paralelamente a esse dado - que todos os autores reconhecem por ser essa uma tendência mais ou menos consensual - há outra, de extrema relevância: o aumento do trabalho precarizado em escala mundial, o aumento do proletariado precarizado.

TRABALHO PRECARIZADO - A expressão trabalho precarizado é aqui utilizada porque, no mundo do trabalho, as formas de terceirização significam precarização, mesmo que seja a terceirização de trabalhadores qualificados. Aqueles que têm capital cultural podem se terceirizar com maior tranqüilidade; mas como o inspetor de qualidade, por exemplo, será reconvertido num mundo produtivo no qual sua função desaparece? Como o trabalhador da época do taylorismo e do fordismo - com 10, 15 ou 20 anos de experiência - que tenha sua especialização eliminada, poderá ser reciclado para o mundo produtivo? Essa segunda tendência não apenas contradiz a primeira - de que a classe trabalhadora estaria em processo de eliminação -, mas mostra acentuadamente que a classe trabalhadora vive também um processo de expansão no universo do trabalho precário, o que em si já representa enorme problema quando se pensa na questão sindical, no interior mesmo das próprias classes trabalhadoras.

Uma terceira tendência poderia ainda ser apontada: o aumento crescente do trabalho feminino. Em muitos países avançados, cerca de $40 \%$ da força de trabalho já é composta por mulheres, não só no ramo têxtil - em que sempre estiveram presentes -, mas também no setor de serviços e no ramo microeletrônico. Os dados demonstram que o trabalho feminino, nas décadas de 80 e 90, tem vivenciado uma expansão exatamente no espaço do trabalho precarizado.

Essas tendências apontam para um processo de maior heterogeneização e fragmentação das classes trabalhadoras o que, entretanto, não pode ser visto como eliminação das mesmas. Conseqüentemente, não se pode afirmar que tais tendências não mais se aplicam às classes trabalhadoras porque elas teriam desaparecido. Uma importante conseqüência, relacionada também ao trabalho feminino, quer pela sua forma precarizada, quer pela sua condição de gênero, refere-se aos sindicatos. Em geral, mesmo o sindicato classista, mais 
combativo, é fortemente masculino em sua concepção. Assim, torna-se um desafio para os sindicatos incluir os trabalhadores precarizados, incluir efetivamente a mulher que trabalha fora, muitas vezes duplamente excluída do sindicato por ser mulher e atuar de forma precarizada no mercado de trabalho.

Há no mundo globalizado um exemplo muito forte dessa situação, por sua evidência. No cenário atual, surgiram novos países industrializados. O tênis Nike é produzido na Indonésia por mulheres que recebem US\$ 38 por mês, com uma jornada de trabalho de 60 horas por semana. É esse o admirável mundo novo: trabalha-se um mês, produz-se milhares de tênis, para no final desse período não se ter recursos para comprar sequer um único par do tênis Nike no mercado mundial globalizado.

Em Bangladesh também há diversas empresas que procedem da mesma forma, empregando mulheres trabalhando mais de 60 horas por semana, ganhando menos de US\$ 30 por mês. O trabalho, assim, precariza-se em várias regiões, não só naquelas em que há o desemprego estrutural, a expulsão do trabalho, mas também naquelas onde a inserção se dá sob condições extremamente precárias. Além disso - e esta é a quarta tendência - há a exclusão de jovens e de velhos, que não encontram espaço no mercado de trabalho, além da inclusão criminosa de crianças no processo de produção.

FRAGMENTAÇÃo E REORDENAMENTO - Vive-se, assim, em um cenário de muita fragmentação e heterogeneização. A esses elementos um outro pode ser adicionado, não menos importante que os anteriores: a existência de diversos segmentos que se qualificam no trabalho, como no campo siderúrgico, e outros que se desqualificam ou mesmo desaparecem, como os gráficos, os operários da construção naval, os mineiros. Poder-se-ia desejar que os mineiros desaparecessem - por vivenciarem, indubitavelmente, um trabalho muito violento - se a desaparição de sua condição de mineiros significasse sua conversão para outro tipo de trabalhador, que passasse a vivenciar uma vida dotada de algum sentido no trabalho. Infelizmente, não é o caso. As estatísticas indicam que em regiões inteiras da Inglaterra, em Criciúma ou em outros lugares, a eliminação da sua condição de mineiro é a inscrição para o bolsão de miseráveis que existe hoje em abundância no cenário mundial.

Isso não quer dizer que o trabalho desapareceu, mas que o trabalho social combinado de que falava Marx é mais heterogêneo, mais fragmentado e inserido no contexto internacional. Qualificado ou desqualificado, estável ou precário, há muitas classificações para o homem que trabalha, a mulher que trabalha, o jovem que trabalha, o mais velho que é excluído, o operário nacional e o imigrante. Teria a criação de valores perdido o seu sentido? Eu penso que não.

Mitsubishi, IBM, Toyota, Volvo, Volkswagen, General Motors fabricam produtos que resultam da interação do trabalho vivo com o trabalho morto, ainda que seja um trabalho vivo que se reduz nesse processo produtivo extremamente fragmentado. Apesar da classe trabalhadora estar mais fragmentada, não se pode falar em fim da teoria do valor, a menos que se aceite a mundialização atual como não sendo a mundialização dos capitais ou do modo de produção voltado para a expansão do capital, algo difícil de sustentar. Em verdade, esse cenário atual nunca foi tão intensamente capitalista, o que reitera a vigência da teoria do valor, por mais que no plano ideológico o capital tente eliminá-la. Em sua expansão, o capitalismo vem criando desafios muito importantes para o espaço sindical.

À empresa verticalizada da fase taylorista-fordista, corresponderia um sindicato também verticalizado Esse quadro alterou-se intensamente. A Toyota, por exemplo, tem cerca de 20 a 25 mil fornecedores. Esse espaço horizontalizado horizontalizou as próprias classes que vivem do trabalho. Ou o sindicato torna-se mais classista, mais abrangente em sua ação, mais horizontalizado, ou seu espaço será cada vez mais reduzido, localizado no topo da 
classe trabalhadora, excluindo a massa imensa e crescente que hoje compõe o trabalho precarizado. Há uma massa de trabalhadores que tem seus direitos subtraídos em nome da modernidade e da competitividade, muito positivas e imensamente produtivas para o capital, mas fortemente destrutivas para o mundo do trabalho. É fundamental que o sindicato incorpore esse conjunto da classe trabalhadora, hoje fora do espaço sindical.

Por fim, é fundamental que o mundo do trabalho e seus organismos de representação, como os sindicatos, tenham claro o caráter destrutivo das mudanças referidas e ofereçam uma alternativa claramente contrária à lógica do capital.

\section{O novo paradigma tecnológico}

Glauco Arbix (Unicamp) - A indústria automobilística vem sendo o principal produtor - e irradiador - de inovações tecnológicas desde Ford, e continua mantendo sua posição neste final de século.

A atual transição de um regime tecnológico para outro só está sendo possível graças à manifestação de um núcleo - cluster - de inovações, baseado em novas tecnologias, com impacto sobre toda a arquitetura industrial das econo-mias mais avançadas (9).

O desenvolvimento da microeletrônica - e a aplicação de sua matriz tecnológica a um conjunto de produtos e serviços - propiciou a conexão de uma série de indústrias e segmentos sob a forma de um complexo altamente articulado. A constituição desse cluster de inovações, capaz de penetrar em praticamente todos os setores da economia, está configurando o surgimento de um novo paradigma tecnológico vinculado à formação de novos setores produtivos e a transformações profundas na estrutura de produção (10). Ou, se quisermos resgatar os termos inicialmente fixados por Schumpeter (11), "novos paradigmas" estariam associados ao surgimento de "inovações primárias".

Algumas condições centrais para a configuração do novo paradigma podem ser encontradas na análise desse novo cluster:

- as inovações podem ser aplicadas de forma abrangente, tanto em bens quanto em serviços;

- sua oferta é crescente e capaz de alimentar a demanda, mesmo em sua fase inicial de difusão acelerada;

- provocam rápida queda dos preços relativos dos produtos portadores de inovações, com redução de custos para os usuários;

- sua utilização produz impacto marcante nas estruturas organizacionais, financeiras e sobre os processos de trabalho;

- são capazes de reduzir os custos de capital e de ampliar a produtividade do trabalho (12).

O novo paradigma está provocando uma onda de inovações dinamizadoras das grandes economias capitalistas nos últimos anos, que vem sendo comparada a uma terceira revolução industrial.

Freeman \& Pérez ampliaram ainda mais o raio de observação desse movimento ao incluir - e enfatizar - as transformações nos processos organizacionais e gerenciais. Em princípio, tais transformações pareciam apenas atender às necessidades de superação de gargalos existentes no velho paradigma, mas "rapidamente, mostraram todo seu dinamismo" (13), o que pôde ser visto de forma flagrante na indústria automobilística japonesa. 
DESCONTINUIDADES DA TRANSIÇÃo - Como sempre, o período de passagem do velho para o novo paradigma carateriza-se por alterações estruturais profundas que beneficiam e penalizam desigualmente as economias e as nações.

Se atentarmos para o regime tecnológico que predominou no pós-guerra, veremos que era baseado no baixo custo do petróleo e dos materiais intensivos em energia.

Esse regime, que teve uma de suas expressões maiores na indústria automobilística, solicitava um tipo de organização da produção baseada em grandes plantas, com processo contínuo e linhas de montagem, fabricando grandes quantidades de produtos idênticos.

A formação das corporações transnacionais como grandes conglomerados praticamente auto-suficientes, com integração horizontal e vertical, aparecia como resultado quase natural desse estilo produtivo.

Porém, a disseminação do novo paradigma está promovendo verdadeira reviravolta na organização e no gerenciamento da produção industrial, abalando particularmente as grandes corporações. A utilização intensiva das tecnologias de informação está permitindo a superação dos conceitos de automação e mecanização, além de estimular a integração dos processos de concepção, gestão, produção e marketing.

O complexo eletrônico que está tomando forma já é, hoje, praticamente tão forte quanto o complexo automotivo, centro nervoso da economia mundial e exemplo da produção taylorista-fordista. Sua evolução está apontando para uma fusão com a técnica das indústrias de máquinas, desenhando um grande complexo eletrônico-mecatrônico (14), prestes a ocupar o lugar da automação não-programável, repetitiva, que marcou a indústria eletromecânica clássica.

As condições para o desenvolvimento desse complexo eletrônico já estavam formadas em meados da década de 70. Mas foi ao longo dos anos 80 que a rápida disseminação do novo paradigma produziu o que Pérez chamou de um "vendaval de destruição criativa" (15).

Simultaneamente, tal destruição vem propiciando o surgimento de novos caminhos para a economia, cujas tendências estão aflorando e se consolidando nos anos 90 , às quais, porém, os países em desenvolvimento só têm tido acesso homeopaticamente e, ainda assim, de forma produtora e reprodutora de exclusão social.

É o que pode ser observado no salto dado pela indústria automotiva brasileira nos últimos quatro anos. Ao lado de surpreendente recuperação indus-trial, do aumento de produtividade e sucessivas quebras de recordes de produção e de consumo, desenvolve-se:

- desestruturação institucional - desativação da câmara setorial, inoperância das políticas de capacitação tecnológica, enfraquecimento dos mecanismos de negociação coletiva;

- perda de consistência e de força das entidades sindicais de trabalhadores - e conseqüente regressão em patamares de emprego e de salários de momentos anteriores -, que acaba por colocar a discussão da reforma das relações de trabalho em marcos distantes de qualquer articulação democrática.

OS ANOS 90 - Diante das profundas transformações por que tem passado a indústria automotiva brasileira desde o início dos anos 90, o movimento sindical ligado umbilicalmente ao setor, que havia exibido raro desempenho e alcançado invejáveis resultados na década de 80, parece perder força e se fragmentar no cenário político e reivindicativo dos dias atuais. 
A dinâmica das mudanças estruturais que percorre o complexo automotivo tem nas grandes empresas seu centro nervoso. Levadas a produzir em novo ambiente econômico, as montadoras transnacionais realizam profunda inflexão em sua trajetória, investindo diretamente no Brasil, de modo só comparável à primeira grande entrada no país nos anos 50, quando do seu nascimento.

A indústria automotiva apresentou o maior crescimento de produção, beneficiandose do maior crescimento do mercado interno do mundo exibido pelo Brasil desde 1993 e de uma série de mecanismos de restruturação industrial possibilitados pela ação do Estado e por um interregno de contratações de médio e longo prazo com os sindicatos, cuja forma mais avançada expressou-se nos trabalhos virtuosos da câmara setorial durante os anos de 1992, 1993 e parte de 1994.

O desempenho industrial então alcançado, que está se confirmando em 1996, tem atraído as atenções dos principais fabricantes de autoveículos, principalmente diante do estreitamento dos mercados em que estão tradicionalmente implantados e dos incentivos propiciados pelo Novo Regime Automotriz definido pelo governo no final de 1995. O novo regime, concebido e decretado diretamente pelo governo sem as discussões tripartites da câmara setorial, acabou por concentrar um poder inusitado nas mãos das grandes montadoras, em detrimento de setores como o de autopeças e os representados pelos sindicatos de trabalhadores.

A abertura da economia no início dos anos 90 revelou uma indústria defasada tecnologicamente, secundarizada por suas matrizes, produtora de envelhecidos modelos e a léguas de distância da best practice, desenvolvida com agressividade por empresas japonesas e coreanas.

Cinco anos depois, assistimos a uma verdadeira reviravolta na indústria automotiva. Tanto o mix de produção quanto a gama de produtos oferecidos mudaram da água para o vinho. Novos veículos foram concebidos e produzidos em tempos recordes. Modelos globais começaram a ser colocados no mercado a partir de melhorias substantivas nos indicadores de qualidade e de produtividade.

As alterações expressam, de fato, novas estratégias das grandes montadoras para o Cone Sul, em especial para o Brasil, que inclui até mesmo a implantação de unidades produtivas inovadoras, como o Condominio Industrial da Ford e o Consórcio Modular da Volkswagen, em Resende (RJ) - que pode vir a se consolidar como a primeira fábrica virtual do mundo, com os fornecedores assumindo diretamente a produção de caminhões no interior da fábrica da montadora alemã.

O quadro brevemente descrito é de contraste aberto com a década passada. Nos anos 90, em especial a partir de 1992 - não por acaso depois do início dos trabalhos da câmara do setor automotivo - as grandes corporações passaram a investir pesado na restruturação industrial, com os olhos voltados para o mercado brasileiro e para a nova arquitetura do Mercosul, alcançando resultados significativos na diminuição do gap existente entre a produção nacional e os padrões internacionais mais avançados. Evidentemente, tal reconversão não se desenvolve tranqüilamente e atinge de forma assimétrica todos os envolvidos na cadeia produtiva do setor.

A importação intensiva de componentes e os novos padrões de preço, de qualidade e de produtividade que as montadoras procuram fixar para os fornecedores estão alterando a estrutura do setor de autopeças, criando novas hierar-quias, fusões e associações de produtores. A crise e o encolhimento desse setor industrial, que desempenhou destacado papel na assimilação e difusão de tecnologia ao longo dos anos 50, 60 e 70, vêm gerando ondas de 
impacto sobre o novo ambiente produtivo - a quebra e o fechamento de empresas é uma realidade - que está sendo formado, sobre o mercado de trabalho e sobre as práticas sindicais.

No interior das fábricas, generalizam-se processos de automação e informatização, de just in time, células de produção, kanban, programas de qualidade total e de terceirização. Em todas as montadoras do $\mathrm{ABC}$ tornou-se voz corrente a valorização da polivalência, do aumento da mobilidade entre postos de trabalho, da incorporação de novas funções ao trabalho, do trabalho em grupo.

Ainda que essas palavras carreguem conteúdos às vezes completamente distintos; que o treinamento e os programas de qualificação das empresas não consigam preparar adequadamente seus funcionários para as novas funções; que haja freqüentemente intensificação do ritmo de trabalho; e que o atual ajuste fustigue com o desemprego e a insegurança os trabalhadores, não há como negar que o panorama fabril do setor está vivendo transformações inéditas nos últimos 40 anos.

Essas mudanças nas estruturas de produção, que atingem a própria malha de relações construídas entre as empresas, empresas-trabalhadores e empresas-trabalhadores-governo, estão sendo introduzidas pelos grandes fabricantes com dois alvos básicos:

- aumentar a participação e o envolvimento de trabalhadores - como indivíduos ou grupos informais - de modo a contornar, senão superar, relações conflitivas, estimulando maior motivação e compromisso com as empresas;

- modificar a organização do trabalho e os sistemas de remuneração, de forma a pressionar por alterações na legislação trabalhista, diminuindo encargos, flexibilizando contratações e diminuindo custos.

Os sindicatos têm conseguido sobreviver a duras penas no interior dessa nova realidade. Sua atuação na câmara setorial demonstrou que são capazes de interferir positivamente na restruturação industrial, na definição de políticas públicas e na proteção de salários e melhoria de condições de trabalho.

No entanto, a construção de um novo estilo de ação sindical, fundamentado na busca de negociações mais permanentes e em acordos mais duradouros com as empresas, não tem se revelado um movimento de fácil consecução: tanto pela história dos sindicatos e pela intensificação do comportamento competitivo das empresas, quanto pelo deliberado distanciamento do governo.

O novo estilo de atuação sindical que começou a se formar no final dos anos $80 \mathrm{e}$ ganhou decisivo impulso a partir das experiências positivas da câmara do setor automotivo baseou-se, politicamente, na perda de vitalidade de várias formas de resolução de conflitos, amplamente utilizadas pelo movimento sindical na década de 80 que começaram a demonstrar evidentes sinais de cansaço com a redemocratização do país. Fundamentalmente, porém, o novo curso assumido pelas principais lideranças da CUT, que passou a exigir das diretorias sindicais, das comissões internas das empresas, dos grupos de fábrica e das Cipas um comportamento mais participativo na definição dos novos rumos da produção e do trabalho, permitiu aos sindicatos dos metalúrgicos, em especial o do ABC, relativa plasticidade para enfrentar o reordenamento industrial.

Nem sempre, porém, os mais diferentes organismos de representação dos trabalhadores mostraram-se à altura dessas exigências, mesmo quando as mudanças propostas pelas empresas vinham adocicadas por etiquetas mistificadoras, mais afeitas à retórica empresarial do que às efetivas mudanças de comportamento. 
Ainda assim, com esses poréns, as pautas de negociação passaram a ser gradativamente ampliadas no setor automotivo, incluindo agora pontos inimagináveis para o sindicalismo agressivo da década de 80 . Novas negociações e novos acordos passaram a freqüentar as relações entre empresas e sindicatos no setor automotivo.

Em certo sentido, ao procurar um marco de relacionamento mais estável, os acordos celebrados no ABC, de 1992 em diante (em especial os de participação nos resultados, flexibilização da jornada de trabalho e de banco de horas), caminham na contra-corrente, pois procuram constranger aspectos selvagens da restruturação e explorar algumas das potencialidades do novo ambiente industrial. Em outras palavras, ao mesmo tempo em que desenham novos caminhos, diante da ausência de ambientes institucionais amplos e adequados, revelam um fôlego curto, repondo tensões e incertezas.

Os avanços alcançados têm, portanto, dificuldades de se consolidar, estabelecendo-se apenas por breve período. Não raramente curvam-se diante do primeiro obstáculo. Rompem-se diante de uma pressão mais intensa. E a sua instabilidade impede, de fato, a sedimentação de um relacionamento duradouro, baseado nas discussões estratégicas, únicas capazes de indicar caminhos para a diminuição de incertezas, tanto para a indústria quanto para os trabalhadores.

Os sucessivos avanços e recuos no relacionamento entre trabalhadores e empresas parecem obedecer a uma lógica randômica, típica de quem dispensou a razão em benefício dos humores e do tato. A recusa do governo em incentivar uma estratégia de compatibilização sobre as políticas industriais e as relações de trabalho, que inclua o questionamento democrático da inadequada legislação trabalhista, libera a intervenção das grandes empresas e contribui decisivamente para tornar o ambiente produtivo mais inseguro e gerador de desconfianças. Ou, em outras palavras, favorece a reinstalação de um quadro adverso, conflituoso, com fortes implicações na política sindical e no desempenho produtivo, como a retomada de movimentações grevistas no segundo semestre de 1996 pareceu anunciar.

\section{O desemprego estrutural}

Sergio Mendonça (Dieese) - Ao discutir o impacto do fenômeno da globalização nas relações de trabalho, nota-se que o termo, na verdade, representa uma tendência já existente no capitalismo há muito tempo, tendência essa de buscar a ampliação de seus espaços, de seus mercados e que, nesse momento específico, toma essa denominação.

O principal ponto a ser aqui tratado é a discussão do desemprego estrutural. Vive-se atualmente período semelhante aos vários séculos de existência do capitalismo, aos vários períodos de baixo crescimento econômico. As mudanças tecnológicas, as mudanças na reestruturação produtiva, as mudanças organizacionais estão provocando maior desemprego em alguns países, o chamado desemprego estrutural. Entretanto, não seria esse desemprego muito menor se não ocorresse agora um período de maior intensidade do crescimento econômico? Ou seja, se considerarmos os 30 anos que se seguiram à Segunda Guerra Mundial, notaremos que esses foram anos de intenso crescimento econômico, fazendo com que alguns países chegassem muito próximos do chamado pleno emprego.

As duas últimas décadas, por várias razões - inclusive algumas já apontadas no texto de Jacob Gorender -, foram de baixo crescimento econômico, da ordem de $2 \%$ ou 2,5\% ao ano. Em que medida as inovações tecnológicas ocorridas nesse período - inclusive a projeção do Japão - e o acirramento da concorrência teriam provocado menor desemprego se a dinâmica de crescimento da economia mundial tivesse sido mais favorável? De fato, essa é uma discussão que está presente há muito tempo. Ao longo de um período, ainda que limitado, da história do capitalismo, como foi possível a discussão sobre o avanço da pro- 
dutividade e das formas encontradas para enfrentar esse avanço tecnológico - até mesmo gerando empregos -, seja pelo crescimento econômico, seja pelas mudanças - inclusive institucionais - de redução da jornada de trabalho?

A questão colocada é uma questão-chave. A lógica atual do capitalismo é que, ao avançar em algum tipo de crescimento econômico acelerado, haja uma intervenção imediata buscando o controle da inflação, buscando até mesmo obter pressão deflacionária para que a rentabilidade das aplicações financeiras seja garantida. Do ponto de vista da globalização, tal fato também se aplica ao caso brasileiro. Por quê? Porque a inserção na globalização, associada a um baixo crescimento da economia mundial, coloca hoje a verdadeira realidade que já vem dos anos 70, com o ascenso do Japão. A ascensão de determinado país ou de vários países na atividade econômica mundial vem, em geral, acompanhada da diminuição de espaço dos demais. É como na história de Alice no país das maravilhas: "quanto mais houver de seu, menos haverá de Deus". Portanto, não existe muito espaço para uma economia de empréstimo havendo muito mais concorrência, como é o caso da China atualmente, das brigas setoriais, da indústria automobilística.

O CASO BRASILEIRO - Para o Brasil, a década de 80 foi marcada por oscilações. Foram anos de crescimento, estagnação, recessão, volta do crescimento. Ainda existia associação entre crescimento econômico e geração de empregos, fato que pode ser claramente observado nos anos 1981, 1982 e 1983. Em 1984, 1985 e 1986 o emprego cresceu, em 1987 e 1988 caiu, seguido por certa estagnação. Em 1989 o crescimento econômico voltou, levando à queda do desemprego e aos menores índices de desemprego da década. No final dos anos 80 , apesar da situação de dificuldade econômica, ainda havia associação entre crescimento econômico e geração de empregos.

Já nos anos 90, mesmo com o crescimento econômico total da ordem de $15 \%$ por três anos consecutivos (1993, 1994 e 1995), a taxa de desemprego - que já havia atingido patamares de 16\% na região da Grande São Paulo, com taxas parecidas em outras regiões metropolitanas do país - não cai, apenas oscila de 16 para $13 \%$, e com apenas um ano de recessão já volta aos $16 \%$. Dessa forma, a discussão sobre desemprego estrutural traz consigo várias indagações. Em que medida o velho crescimento econômico, em uma escala apropriada, e sustentado, responde ou não à geração de empregos?

No caso brasileiro, vale a pena destacar alguns aspectos quanto a mudanças ocorridas no mercado de trabalho. Houve mudança ocupacional muito expressiva, redução brutal do emprego industrial, aumento do emprego no chamado setor de serviços. Mas o que seria esse setor de serviços? Qual é a dinâmica desse setor? Quais são os subsetores do setor de serviços que têm dinâmica atrelada ao setor industrial? Se tal relação não for estabelecida, permanece a idéia de que o setor industrial está perdendo importância, quando, na verdade, é esse setor que vai dar nova dinâmica à economia, pois é sabido que boa parte dos subsetores dos grandes setores de serviços estão associados ao dinamismo industrial. Portanto, essa mudança ocupacional, que é muito expressiva - na Grande São Paulo, a região mais industrializada do país, cerca de 700 mil empregos industriais foram eliminados em seis anos, uma mudança radical relacionada à mudança da estrutura de organização industrial da região -, está ligada à questão da terceirização e ao que se passa atualmente no movimento sindical.

A discussão sobre se a oferta de empregos aumenta ou não com o crescimento econômico está rompida. Os economistas afirmam agora que a elasticidade da relação entre o produto e o emprego é que determina o crescimento, ou seja, que certa taxa de crescimento do produto provoca determinada taxa de crescimento de emprego. Assim, essa é uma questão ainda sem resposta. Sabe-se que é preciso haver mais crescimento para que a mesma quantidade de empregos existente no modelo anterior, presente nas décadas de 70 e 80 , possa ser gerada. 
REPRESENTAÇÃO SINDICAL - Quanto às relações do trabalho, sabe-se que todas as estruturas de representação e todas as formas de organização estão em xeque, inclusive os partidos políticos, devido ao avanço de uma visão cada vez mais individualista, mais liberal, que rompe com a solidariedade. Há, ainda, um estreitamento da base de representação sindical. Em 1989, o sindicato dos metalúrgicos do ABC, o mais atuante do país, representava 190 mil trabalhadores. Hoje, representa 130 mil, e com esse estreitamento, além de perder sua capacidade de financiamento e de uma série de outros aspectos, o sindicato encontra mais dificuldades para representar os interesses dos trabalhadores.

No mundo inteiro, como apontado por Ricardo Antunes, o movimento sindical foi estruturado com base no trabalhador do sexo masculino de 35 a 40 anos, o chamado colarinho azul, um operário do chão de fábrica. Na medida que os acordos dessa estrutura são rompidos e as novas unidades de produção ficam menores, o número quantitativo de trabalhadores é, em escala, superior, porque o movimento sindical tem de se reciclar para dar conta dessa nova ordem de interesses. Isso ainda não está colocado, levando ao seguinte questionamento: a partir desse novo modelo de produção, por onde deve caminhar a estrutura sindical?

Antunes afirma algo muito interessante: a classe operária não está diminuindo, ela está se fragmentando cada vez mais. Há maior participação feminina, maior quantidade de trabalho precarizado, o que coloca mais desafios à possibilidade de retomada da capacidade de representação sindical. Há uma grande dúvida - mesmo entre membros do governo -, relacionada à pressão da entrada do Brasil no cenário internacional, sobre se se deve optar pelo sindicalismo de empresa ou pelo sindicalismo centralizado. Efetivamente, parece que o Brasil não caminha para o modelo sueco, até porque o modelo suéco-dinamarquês-norueguês está sendo repensado. Mas há uma resistência enorme do movimento sindical brasileiro em optar pelo sindicalismo de empresa, semelhante ao modelo norte-americano, o qual encontra sua expressão máxima no chamado modelo japonês, que possui aproximadamente 75 mil sindicatos, praticamente um sindicato por cada empresa média ou grande.

Outra questão fundamental a ser pensada refere-se à capacidade de representação sindical no local de trabalho nesse novo modelo de produção. Os trabalhadores são capazes de oferecer sugestões, alternativas, proposições, de tentar defender seus interesses quanto mais eles conheçam a nova forma de produção? Não é por acaso que o exemplo da Mercedes Benz foi aqui citado, pois é em empresas desse porte, principalmente na região do $\mathrm{ABC}$, que há o maior grau de organização dos trabalhadores no Brasil. Os trabalhadores da Mercedes chegaram a discutir, antes da crise das demissões, a questão dos grupos de trabalho, tema bastante avançado para a realidade brasileira, apresentando um nível de organização em que a comissão de fábrica é capaz de dar sugestões sobre como organizar a produção dentro da fábrica. A questão tem profunda relação com a da representação sindical no trabalho.

EMPREGABILIDADE E EDUCAÇÃO - Há, ainda, duas outras questões extremamente importantes relacionadas à discussão sobre a globalização, o toyotismo, as novas formas de produção. A primeira é saber se hoje há de fato essa incapacidade da economia de gerar empregos. Considerando as dificuldades apontadas anteriormente e a crescente fragmentação dos trabalhadores, os sindicatos têm necessidade de incorporar temas mais abrangentes. Não há tema mais abrangente que o do emprego, porque é exatamente esse tema que permite fazer uma ponte entre a representação dos incluidos e a representação dos excluídos. Entre os excluídos, há aqueles que, apesar de desempregados, ainda estão próximos ao mercado de trabalho por estarem procurando emprego; entretanto, há aqueles que sequer estão no desemprego por se encontrarem em situação absolutamente precária e de pobreza, com relação aos quais a atuação do Estado deve ser de outra ordem. A discussão sobre empregos é, assim, uma discussão que pode mobilizar e estabelecer a relação entre os incluídos aqueles que ainda resistem no chamado emprego formal - e os excluídos. 
A segunda questão está diretamente relacionada à nova forma de organização do trabalho. Trata-se da idéia de que está surgindo um novo trabalhador, mais qualificado, abrangendo a discussão sobre o impacto da educação básica nos trabalhadores. A discussão sobre a formação profissional e a empregabilidade é uma dimensão que pode ser aprofundada, já que se corre o risco de jogar para a responsabilidade individual dos trabalhadores a tentativa de se colocar num novo mercado de trabalho, bastante adverso. Tal noção implica que cada trabalhador deva ser inteiramente responsável pela sua vida profissional para estar o tempo todo empregado e, de certa forma, desloca da responsabilidade da sociedade e do Estado o papel de atuar sobre a política econômica, sobre as mudanças institucionais e legais no sentido da geração de empregos. Mas é sabido que não adianta o trabalhador ter qualificação de altíssimo nível se não houver empregos sendo gerados.

Como exemplo, pode-se citar a Alemanha. Provavelmente, é o trabalhador alemão quem possui o maior nível educacional do mundo. Entretanto, discute-se naquele país como seria possível agregar mais dois ou três anos a essa qualificação. O trabalhador alemão tem, em média, catorze anos de estudo, mais que o trabalhador norte-americano ou japonês. Entretanto, a taxa de desemprego na Alemanha, desde 1980, não consegue se situar abaixo dos $10 \%$, até mesmo aumentando após a unificação. Portanto, é preciso cautela ao se discutir o que seria essa avaliação do novo trabalhador mais qualificado, polivalente, e as políticas que, de certa forma, são as que atuam apenas sobre a oferta de trabalho e não sobre a demanda de trabalho, não enfrentando diretamente a questão do desemprego.

Um último aspecto deve ser colocado. Ao contrário do que foi dito anteriormente, penso que o governo federal não possui uma política industrial, um programa brasileiro de controle da qualidade e da produtividade. Mais recentemente, pode-se citar, nesse sentido, o programa de apoio à capacitação tecnológica da indústria. São instrumentos como esse que o governo utiliza para tentar integrar o Brasil à economia mundial e para apoiar as empresas. Muitas delas buscaram se reestruturar, inclusive baseadas no chamado modelo japonês.

Ainda nesse sentido, em breve será iniciada pelo governo uma discussão no Conselho Nacional do Trabalho sobre as mudanças na estrutura sindical e nas relações de trabalho, envolvendo a busca de um acordo entre o governo e as principais centrais sindicais do país quanto à mudança na direção do contrato coletivo, fim do imposto sindical, diminuição da tutela do Estado, questão do poder da Justiça do Trabalho. Portanto, há, sim, em curso, um claro modelo, mas que, evidentemente, tem por trás uma visão de inserção à economia mundial, esta se colocando como determinante da política econômica adotada. Dessa forma, são agregadas certas políticas que talvez não representem a política industrial que alguns setores da sociedade considerem ideal, mas que se adequam à visão mais geral do regime vigente.

\section{O futuro dos sindicatos}

Alvaro Augusto Comin (Cebrap) - Questão colocada anteriormente, a precarização do trabalho é fenômeno extremamente importante quando se discute o desemprego. Talvez a questão da precarização do trabalho, nesses tempos de globalização, seja tão ou mais importante que a própria questão do desemprego, até porque em mercados desestruturados como o brasileiro, mascara o problema do desemprego. Se o problema está agora se tornando grave nos países desenvolvidos, é uma questão quase secular no Brasil. Essas novas formas da organização do trabalho tendem a contribuir para o agravamento da questão do desemprego. Além do mercado informal clássico, passa a existir também a situação de informalização e precarização do trabalho, moderna e perfeitamente sintonizada com o novo momento político dos Estados Unidos. Nas grandes empresas, há trabalhadores bem pagos, com boas condições e bons contratos de trabalho; paralelamente, um mercado precarizado, com baixos salários. Essa é uma questão absolutamente central. 
Quanto ao poder sindical, a revolução tecnológica não implica necessariamente enfraquecimento dos sindicatos, mas os direciona para uma mudança qualitativa. Que mudança seria essa? A tendência à fragmentação do poder sindical e as mudanças que se operam nos mercados de trabalho podem até contribuir para o fortalecimento dos sindicatos. Na verdade, é a base tradicional dos sindicatos, formada pelos trabalhadores mais qualificados, que está sendo mais preservada pelas mudanças no sistema produtivo. Esses são os trabalhadores que tradicionalmente compuseram, e compõem, a base dos sindicatos. Nesse sentido, os sindicatos não vão necessariamente se enfraquecer; a tendência é que sejam empurrados a um tipo de ação fragmentada, que opere em nível das empresas.

Fator bastante preocupante, entretanto, é a tendência da dualização do mercado de trabalho. Pode haver sindicatos organizados, porém operando em nível das empresas, cuja ação não tenha qualquer efeito sobre aqueles que estão fora do reduzido mercado de trabalho ou sobre o próprio Estado.

\section{A opinião da CUT}

José Lopes Feijóo (CUT) - Durante certo tempo, foram exatamente as lutas quanto à questão da informalidade do trabalho, pela eliminação do trabalho infantil e das pesadas jornadas, pela formalização das relações de trabalho, que deram vida e fortaleceram a ação sindical. Talvez este seja o momento de retomar tais ações, de retomar essa discussão. Entretanto, é preciso lembrar que existem dois tipos de informalidade. Existe a informalidade do trabalhador contratado de forma informal, mas com um claro vínculo empregatício e, portanto, sujeito a um tipo de representação, e o trabalhador informal que não tem contrato com ninguém a não ser com ele mesmo e que, embora sem perceber, faz parte do contingente que está na economia ajudando os setores produtivos e a comercialização de produtos. Não se trata de querer impedir a existência de microempresários, mas de apontar que este é um trabalhador que está sendo explorado no sistema produtivo.

O sindicato participa em período integral das negociações feitas pela comissão de fábrica. Há uma prática desenvolvida no $\mathrm{ABC}$ pela qual o sindicato é mais abrangente e cuida das questões de toda a categoria, mas há também um processo de organização no local de trabalho por meio das comissões de fábrica. Portanto, há uma interação. Não existe monopólio embora, na maior parte do movimento sindical, ele se dê de fato por ser um monopólio da entidade sobre os trabalhadores quando deveria ocorrer exatamente o inverso: o monopólio dos trabalhadores sobre a entidade. É nesse aspecto que deve haver reorganização.

Embora a Constituição de 1988 tenha modificado alguns de seus pontos, o atual modelo sindical ainda é enfraquecido por amarras maiores que permanecem. O imposto sindical, por exemplo, garante uma fonte de receita para a sobrevivência do sindicato mas, na prática, é uma fonte de receita para impedir que ele se organize. A partir do momento em que o sindicato tem receita garantida pelo imposto sindical, isso faz com que ele não precise ter associados, mas apenas o monopólio de representação. Tal fato enfraquece o próprio sindicato; não o fortalece absolutamente por criar as condições necessárias para que ele não tenha qualquer relação com suas bases. O sindicato não precisa de sócios, não precisa ir às fábricas no dia-a-dia, trabalhar, conseguir que as pessoas se convençam da sua importância, e por quê ele é importante.

Atualmente vive-se um momento de transição bastante interessante. Se, por um lado, há pressão para que haja um sindicalismo por empresa, por outro, não é menor a pressão, principalmente no âmbito da CUT, para um novo padrão de organização sindical fundado na liberdade, na autonomia, no direito dos trabalhadores se organizarem, no fim do poder normativo da Justiça do Trabalho, na extinção de todas as formas de intervenção estatal. 
Uma legislação de sustento que garanta o direito de organização e não finja garantir, ao mesmo tempo, que proíbe, uma legislação que permita aos trabalhadores se organizarem com competência, sem intervenção, podendo desempenhar o papel que o Estado faz atualmente. Essa é a grande batalha travada pelos sindicatos neste momento. Instituir um modelo de organização sindical no qual os trabalhadores tenham o direito de exigir e de atuar.

\section{As lições da Alemanha}

Flávio Kothe (IEA-USP) - A globalização não provoca problemas apenas no Terceiro Mundo, mas também no Primeiro e no Segundo; ela beneficia o Primeiro, às custa do Terceiro. Tende-se a repetir aqui o clichê esquerdista, de que a riqueza das metrópoles decorre tão somente da pobreza da periferia e, portanto, esta é uma seqüela. Em Rostock, por exemplo, na antiga República Democrática Alemã, o número de empregados na indústria naval, depois da reunificação alemã, caiu de 27 mil para 7 mil e ainda mais, posteriormente, numa cidade com 250 mil habitantes. O que representava encomendas dentro do sistema socialista, evitando em parte o impacto direto da concorrência internacional, não conseguiu enfrentar os preços baixos dos tigres asiáticos.

Houve lugares na antiga RDA que, com a reunificação, atingiram índices de desemprego na ordem de $90 \%$. No Brasil não se sabe ainda o significado de ter $50 \%$ de desempregados que já não têm mais qualquer perspectiva de trabalho. No socialismo, essas pessoas não tinham visto desemprego, embora muitas vezes houvesse mais gente empregada para fazer um trabalho do que o necessário, o que tornou o sistema improdutivo e o levou à falência.

Uma das causas do desacerto econômico do socialismo de Estado foi que, nele, os preços geralmente não estavam corretos, mas não no sentido do capitalismo, no qual sempre se paga mais do que o bem custa para ser produzido. Nele havia uma divisão entre o que era considerado bem necessário, vendido abaixo do preço de custo, e o bem de luxo, vendido bastante acima do custo. Luxo era aquilo que um operário não costumava consumir, mas segundo o padrão de vida do século XIX.

Batata e cerveja eram então vendidas a preços muito baixos; televisão e automóvel, a preços muito altos. Havia, portanto, uma ideologização geral dos preços. O Partido não deixava o operário acompanhar a evolução que o capitalismo avançado tinha proporcionado, como não favorecia a iniciativa privada para o setor de serviços. Inibia a liberdade de expressão e de ir e vir, acabando por acarretar a falência do sistema que ele pretendia defender.

Com a penetração do capitalismo na Alemanha dita Oriental (na verdade, Central, já que a parte alemã oriental foi incorporada à Polônia, à Tchecoslováquia e à Rússia, com a expulsão de 11 milhões de alemães em 1947-48) o desemprego aumentou por toda a parte, inclusive porque não interessava à indústria e ao comércio da antiga Alemanha Federal manter as empresas concorrentes.

Criou-se um colonialismo interno e milhões de pessoas perderam seus empregos. Os intelectuais da RDA, muitas vezes, não tinham chance de trabalho por discriminação ideológica. Pessoas altamente qualificadas ficaram sem qualquer perspectiva de vida. Os desempregados com mais de 45 anos de idade só poderiam esperar a morte. A discriminação política tornou mais drástica a tendência da globalização da economia com o desemprego crescente de profissionais altamente qualificados. O governo precisou inventar lazer para essas pessoas. Uma das saídas foi oferecer programas culturais ou esportivos, sendo favorecido o mais barato.

Numa sociedade com a ética protestante do trabalho, o desempregado tende a se considerar inútil, sem ter mais o direito de viver. A Alemanha tem seis milhões de desempre- 
gados, além de cerca de seis milhões de estrangeiros oriundos de países mais pobres. É evidente que tal fato gera conflitos, mais ainda em uma país que carrega o peso e o preço do período em que foi nazista. Vi enorme preocupação de pessoas e entidades alemãs no sentido de resolver, do melhor modo, esses choques internos, bem como no sentido de encontrar um meio de ajudar a miséria e a espoliação existente no Terceiro Mundo.

Não existe apenas a contradição entre metrópole e periferia, mas diferenças brutais dentro das metrópoles. A miséria da periferia tem como causa problemas mais de ordem interna do que externa, podendo a globalização trazer uma série de vantagens e soluções. Falta desenvolver modelos alternativos e utopias explícitas dentro da dramática situação que se vivencia atualmente e que o neoliberalismo não vai resolver. A discussão tem se limitado ao horizonte restrito do capitalismo, esquecendo-se inclusive formas alternativas de socialismo, diferentes do sistema autoritário e centralizado que falhou na Europa e cujos erros precisariam ser melhor entendidos. Em vez da espoliação capitalista de todos em benefício dos proprietários, poderia ser pensado, por exemplo, um sistema de empresas controladas pelos operários que nelas trabalhassem ou observar melhor por que a China é a economia que mais se desenvolve no mundo.

\section{A informalização no mercado de trabalho}

Gilberto Dupas (IEA-USP) - Três características fundamentais marcaram as tendências do mercado de trabalho nas últimas décadas: a aceleração do desemprego tecnológico, a terceirização e a informalização das relações de trabalho.

Um enorme avanço da pesquisa de ponta passou a viabilizar brutais saltos em produtividade, garantindo altas taxas de acumulação. O capitalismo da economia global passou, então, a alimentar sua dinâmica com o crescimento dos salários reais dos empregados, viabilizado por progressiva qualificação da mão-de-obra especializada e sistemas altamente automatizados. Por outro lado, o número de empregos gerados por dólar adicional de investimento direto entrou em declínio, reduzindo a taxa de geração de ocupações. Como o setor serviços foi tomado igualmente por intensa automação, evaporou-se a fantasia de que ele absorveria os excedentes de pessoal da indústria. Surgiu, então, o desemprego estrutural, a mancha escura na alma do capitalismo vencedor, novo fantasma dessa virada de século.

Outra clara tendência é a expansão da terceirização. Certos serviços e insumos são produzidos mais eficientemente se delegados a pequenas unidades especializadas. É o que acontece com a Nike, um dos maiores produtores globais de sapatos esportivos, cuja corporação emprega diretamente 15 mil pessoas. Seu escritório central atua em estratégia, marketing, concepção de produto e logística de distribuição. Toda a atividade de produção é terceirizada por dezenas de fornecedores e especialistas que empregam, no total, cerca de 80 mil pessoas. A terceirização é um mecanismo eficaz para flexibilizar custos, reduzindo programas sociais, encargos e impostos. Custos fixos viram variáveis. Paga-se ao fornecedor o número de peças, os pratos de refeição servidos, as horas efetivamente trabalhadas. Defeitos no produto, absenteísmo e ociosidade passam a ser problemas dos terceirizados. O resultado é a progressiva informalização das relações de trabalho e queda de qualidade do vínculo com o empregador.

A informalização do emprego aprofundar-se-á com a progressiva sofisticação das telecomunicações e o barateamento da transmissão de dados. O empregado administrativo do futuro trabalhará em sua casa, com seu micro ligado à rede de computadores de uma ou mais organizações para as quais prestará serviços, poupando horas perdidas no tráfego. Poderá ter remuneração horária maior e mais flexibilidade, mas pagará suas próprias refeições, férias, seguro-saúde e fundo de pensão. Um complicado jogo de perdas e ganhos, cujo balanço é ainda prematuro. 
A forte tendência de progressiva informalização das relações de trabalho parece provocar inevitável queda na sua qualidade. O enfraquecimento do vínculo com o empregador formal põe em xeque as chamadas proteções sociais do trabalhador, tão caras dos movimentos sindicais. O fluxo crescente de trabalhadores informalizados olha para o Estado moderno em busca das antigas proteções e o encontra, também, em forte crise. Mergulhado em seus déficits crônicos e padecendo de tradicional ineficiência como prestador de serviços, o Estado declara-se incompetente para amparar um novo contingente que pede e não contribui.

Há, porém, grandes surpresas com relação ao setor informal. Em primeiro lugar, seu vertiginoso crescimento nos últimos anos, atingindo atualmente cerca de $55 \%$ dos trabalhadores brasileiros (exceto setor público e incluídos os autônomos). Além de ter se constituído em grande alternativa ao desemprego formal, o trabalho informal muitas vezes tem possibilitado ganho de renda e maior flexibilidade às pessoas. É preciso, em primeiro lugar, investigálo melhor. Pesquisa pioneira do IBGE, terminada em maio/96 e restrita à cidade do Rio de Janeiro, contém revelações surpreendentes: somente $8 \%$ desses trabalhadores declararam ter escolhido tal atividade em função da perda do emprego no setor formal; $56 \%$ deles estão na atividade há mais de cinco anos; e 30\% há mais de dez anos. Somente $14 \%$ atuam no setor há menos de um ano. A receita média encontrada foi de R\$ 1.131,00. Vários casos de alta remuneração foram localizados, especialmente na prestação de serviços técnicos. Isso quer dizer que a atividade informal, cada vez mais, está se tornando uma opção no Brasil.

O problema nos remete necessariamente à questão sindical. $\mathrm{O}$ papel tradicional dos sindicatos está em crise no mundo todo. A começar pela contradição em sua prioridade central: defender a geração de empregos ou o aumento de salários? A bandeira tradicional dos sindicatos perdeu suas cores numa sociedade altamente tecnificada e em forte globalização. A conseqüência tem sido a forte redução do número de sindicalizados em todo o mundo e a dificuldade crescente em recuperar um papel que, historicamente, foi essencial na luta por um mínimo de dignidade ao trabalhador.

O exemplo mais radical é o dos Estados Unidos. Atualmente apenas 10\% dos trabalhadores privados são sindicalizados, queda enorme para os 36\% de 1953. Em compensação, o corporativismo estatal ganhou terreno, engrossando a participação sindical de $24 \%$, no mesmo ano, para os atuais $38 \%$. Alguns cientistas sociais têm atribuído à maior participação do movimento sindical a razão do desemprego ter aumentado mais fortemente na Europa, apesar de ter preservado melhores salários e direitos para o trabalhador empregado.

A questão revela-se muito complexa e precisa ser aprofundada. O problema permanece: quais serão as bandeiras viáveis para movimentos sindicais em sociedades de crescente informalização, automação e qualificação?

\section{Novas frentes de batalha}

Paul Singer (FEA-USP) - Até agora, enfocou-se muito a indústria em geral - e a indústria automobilística em particular -, com seu modelo de trabalho. A indústria é uma pequena empregadora, no mínimo, desde o fim da Segunda Guerra Mundial. O processo de terceirização é anterior às modificações aqui enfocadas.

Tanto nos Estados Unidos quanto na Europa, ou no Brasil, a indústria, na melhor das hipóteses, emprega $1 / 5$ da força de trabalho, quando tanto. Em geral, esse número é bem menor. Esse enfoque excessivamente industrial lembra um pouco as grandes discussões ocorridas no começo da revolução industrial, época em que a agricultura ocupava entre 60 e $80 \%$ da força de trabalho. Hoje, a agricultura, nos países que não são grandes exportadores de produtos agrícolas, emprega menos de $5 \%$ da força de trabalho. Dessa forma, o debate 
ganharia maior proporção se o setor de serviços fosse discutido com tanta intensidade quanto o desemprego e as mudanças ocorridas na grande indústria, que nunca foi grande empregadora e está sendo cada vez menos.

O setor de serviços efetivamente é o grande empregador atual. Quando se fala em serviços, trata-se fundamentalmente das áreas de saúde e educação, nas quais verifica-se uma tendência de crescimento da demanda de trabalho. Tanto em educação quanto em saúde o crescimento da produtividade de trabalho, em geral, ou é zero ou se dá em detrimento da qualidade. Atualmente, as duas áreas estão crescendo em termos de mercado de trabalho por diversas razões.

Em primeiro lugar, a população mundial está ficando mais velha. Há enorme demanda por cuidados às doenças crônicas de pessoas com mais de 60 anos, demanda inteiramente nova, e não há tecnologias em massa para atender a essas pessoas. Com pouca mão-de-obra, um novo campo de trabalho está se abrindo nessa área. Em segundo lugar, em função de várias transformações tecnológicas e administrativas, há demanda por educação, não só mais prolongada, mas perió-dica e permanente. A Alemanha, adicionando mais dois anos de educação média aos seus trabalhadores, aumentará, dessa forma, o campo das atividades educacionais. Tal alternativa considera, ainda, o fato de que no futuro os trabalhadores vão ter de ser reciclados e reeducados periodicamente ao longo de toda sua vida, o que também não é propriamente uma novidade.

Tanto no campo da saúde quanto no da educação, o grande capital nunca foi a forma padrão de organização, e não vai ser agora. Eu diria que as transformações tecnológicas trabalham no sentido de provocar uma descentralização, como foi mostrado no texto de Jacob Gorender com relação às novas tendências na indústria automobilística, e provavelmente o campo de serviços - que não se restringe apenas à saúde e à educação - irá na mesma direção. O computador dá ao operador, qualquer que seja ele, novas e variadas possibilidades de trabalho relativamente isoladas. Ou seja, estão ocorrendo transformações revolucionárias nas relações envolvidas no trabalho, que vão além do trabalho industrial.

Portanto, as transformações que estão ocorrendo deveriam ser muito mais investigadas. Sobretudo porque parece que a solução para a questão do desemprego não está em tentar preservar os empregos que estão sendo eliminados devido à revolução tecnológica ou às transformações administrativas. Essa tentativa seria como travar uma batalha perdida de antemão. Seria quase impossível reduzir a jornada de trabalho quando $50 \%$ das pessoas está procurando emprego. Em tese, seria correto dividir melhor o pouco trabalho que existe entre todos; seria justo, mas não é algo factível no mundo capitalista moderno.

Enquanto o desemprego estiver tão alto, o desafio será tentar buscar positivamente a possibilidade de reinserir produtivamente milhões de pessoas que estão, no momento, à margem, enquanto há também milhões de pessoas trabalhando feito loucas, em geral de 60 a 80 horas por semana, para poder sobreviver. É preciso considerar o que acontece hoje para, positiva e politicamente, buscar uma ação do Estado, juntamente com os sindicatos, que possibilite a criação de novas frentes de reinserção produtiva. Se tal objetivo for atingido de forma significativa, aí sim, a formação das forças de classes será novamente alterada, e alternativas hoje propostas, como redividir a jornada de trabalho, tornar-se-ão, quem sabe, viáveis.

\section{O modelo do movimento sindical}

Célia (participante) - No Brasil, com o fordismo, as relações de trabalho sempre foram precárias, a não ser num segmento muito pequeno de trabalhadores. Será que a atual dificuldade do movimento sindical não está localizada na questão de seu modelo? 
Aquele modelo fordista que existiu na Europa não foi isento de contradições, e esse modelo corporativista não é questionado na sua essência. Poder-se-ia perguntar se a questão do modelo adotado, quando não leva em consideração as contradições existentes no próprio fordismo, não impede, de certa forma, uma ação sindical mais decisiva, mais efetiva no sentido de retomar aquela velha luta de classes que, acredito, não está ainda derrotada.

\section{A lógica do movimento sindical}

Roseli (ECA-USP) - Com todas as mudanças e modelos, a lógica continua a mesma. A lógica é a do lucro, e caberia perguntar se não foi a lógica do movimento sindical que perdeu seu rumo. Talvez seja preciso resgatar e repensar qual é a lógica desse movimento. Acredito que a lógica da solidariedade é a grande coisa que tem de ser resgatada, porque se o modelo do lucro está excluindo, deixando à margem, destruindo a força produtiva, qual é a lógica que se opõe à isso?

Quando se pensa sobre qual é o modelo adotado pelo movimento sindical, hoje, questiona-se se o fim do imposto sindical é a grande polêmica, se a tutela do Estado está realmente na raiz de toda a problemática. O problema, no entanto, é de outra ordem. Os próprios sindicalistas deveriam pensar nisso, resgatar essa dimensão. O movimento sindical, que trabalha muito mais no eixo do emprego e do salário, deveria desenvolver também um trabalho de criação de uma cultura sindical, de um ponto de vista sobre o próprio conceito de trabalho. A que lógica pertencem os trabalhadores, sejam eles de qualquer setor?

Nesse momento de discussão, se a prioridade é o emprego, como é que deve ser essa discussão? Outra questão bastante interessante é sobre a lógica da globalização, que envolve concentração e fragmentação. Essa é mais uma problemática que o sindicalismo deveria pensar.

\section{A lógica do capital}

Ricardo Antunes (Unicamp) - A idéia de que a lógica mundial do capital é inevitável e nos resta adequarmo-nos a ela não pode ser aceita acriticamente. Não é possível que a humanidade que trabalha olhe para esse cenário, constate que há um bilhão de indivíduos precarizados ou sem trabalho - indivíduos desempregados - e diga que essa lógica é inevitável só porque ela é comandada, digamos assim, pela lógica inexorável do capital. Efetivamente não posso concordar com isso. Esse é um desafio para a humanidade.

A experiência do século xx mostrou que o caminho tentado na Rússia e na China apresentou problemas, por motivos que têm propiciado muitos debates. O fato de aquela alternativa ter sido anulada não significa que devamos concordar com a idéia de que nos resta apenas aceitar a ordem atual e tentar conseguir o que for possível dentro dela. Mesmo porque, para quem dispõe de capital cultural isso é possível, mas para quem dele não dispõe resta a precarização, a destruição, o desemprego, a miséria, a barbárie.

Um dado muito interessante da mundialização, como já foi citado anteriormente, é o Primeiro Mundo estar no Primeiro Mundo e também no Terceiro Mundo, e vice-versa, ou seja, o Terceiro Mundo está aqui e lá. Não é possível olhar para tal cenário e não se dar conta do que está acontecendo. Os anos 90 estão sendo mais tensos que os anos 80, e devemos estar preparados para mais tensões porque elas virão.

Particularmente, acho essas tensões muito positivas porque são tensões que vêm do mundo do trabalho, fazem com que os trabalhadores comecem a olhar esse cenário e a se dar conta de que maior participação e maior envolvimento não têm impedido a destruição dos direitos trabalhistas. 
Se olharmos o início da década de 90, com a tensão de Los Angeles em 1992, a greve da França em 1995, as experiências sindicais e de greves européias, veremos que são exemplos de resistência e retomada das lutas dos trabalhadores. O México foi citado como um exemplo maravilhoso de alternativa para a América Latina; mas quem conhece o México sabe que se trata de um país socialmente destroçado, que só conseguiu visualizar alguma perspectiva depois que o Movimento Zapatista começou a falar pelo conjunto dos excluídos do país, mostrando-se como exemplo para a América Latina, até mesmo transcendendo o continente latino-americano.

Há um cenário atual configurado, mas ele não é necessariamente o caminho inevitável. A globalização destrutiva só é inevitável sob a lógica do capital. Aí se coloca um desafio que tantos aqui levantaram: ou os sindicatos entram nessa lógica porque ela é inevitável, ou escolhem outro caminho que é muito difícil - os franceses optaram por isso em sua greve, e houve um eco nascido das bases dos trabalhadores - dizendo: "assim não". Os trabalhadores franceses das empresas públicas desejam preservá-las enquanto empresas públicas, e não querem aceitar com muita tranqüilidade que suas conquistas históricas desapareçam.

Quando uma região está sendo desindustrializada e a perda de empregos é enorme, a tarefa dos sindicatos é tentar respostas imediatas. Tal ação é imprescindível e é isso que move, em parte, o sindicato. Entretanto, os sindicatos têm nos mostrado uma grande lacuna: não conseguir visualizar um cenário alternativo a esse. Como já foi mencionado, é muito importante a luta pela redução da jornada de trabalho. Contudo, não se pode acreditar que o capital - seja japonês, alemão, norte-americano, canadense ou italiano -, num pesado momento de competitividade, de salve-se quem puder, vá aceitar facilmente a jornada de trabalho sem redução de salários, numa situação em que até a Suécia está, gradativamente, diminuindo o seu Welfare State.

Dessa forma, é muito importante que possamos olhar para esse cenário e dizer que sua inevitabilidade se dá apenas quando se atua dentro de sua própria lógica, ou, quando se participa dela, mas é possível tentar travá-la, lutar contra ela. Essa dualidade está inteiramente presente hoje, ainda que numa situação mais defensiva. É natural que um século, em que aconteceu o fim do Leste Europeu, da União Soviética e de boa parte das experiências que tentaram ir além do capital, apresente em seu final uma situação defensiva. Mas há muitas vozes, até no interior dessa lógica do capital, que têm acenado para seu caráter destrutivo. Recentemente, o secretário do Trabalho dos Estados Unidos alertou para o fato de que se está levando longe demais a destruição do direito do trabalhador, porque a possibilidade de volta de tensões sociais com muita intensidade preocupa o capital. Até porque o capital sabe por onde e por quem pode ser desmontada essa possibilidade.

ALTERNATIVAS - Fala-se muito das transformações da história, das funções que o mundo apresenta, e esquece-se de pensar que, entre essas funções, uma delas é ir para além do capital, uma alternativa que quebre essa ordem atual. Com certeza, esse não é um empreendimento fácil, mas também não se coloca como alternativa impossibilitada. A reprodução do conjunto da classe trabalhadora é cada vez mais difícil; mas se há lutas sociais, há classes sociais. Se o capital depende ainda de uma forma, qualquer que seja ela, de trabalho vivo, não dá para dizer que esse sujeito coletivo tenha desaparecido.

Além disso, não acredito na volta ao fordismo, assim como também não tenho a idéia de que a alternativa esteja entre o toyotismo e o fordismo. É preciso ir além de ambos. Há uma tese muito difundida hoje no mundo acadêmico, não apenas no Brasil, de que o toyotismo e as formas flexibilizadas de trabalho - na medida que provocam o abrandamento das relações capital e trabalho dentro da fábrica - seriam mais positivos. Esse abrandamento existe, mas decorre da aceitação que esses segmentos, que compõem a classe trabalhadora, têm de mostrar nessa ordem atual. É um abrandamento muito calculado. Nesse sentido, o toyotismo 
seria tão ou mais nefasto para as classes trabalhadoras que o fordismo. Ao se afirmar isso, não se está defendendo aqui qualquer dos dois sistemas. O desafio do mundo do trabalho é estruturar uma forma de sociabilidade que vá além do capital, que vá além do toyotismo e do fordismo.

Tendo em vista o que foi colocado, pode-se dizer que tem faltado ousadia aos sindicatos, que se encontram em uma luta defensiva. Lutar contra a ordem? Calibrar isso é muito difícil, mas esse é um desafio, e se os sindicatos não forem capazes de fazer isso correm o risco de enfraquecer muito. $\mathrm{Na}$ década de 80 , os sindicatos foram muito fortes no cenário brasileiro. Enquanto o sindicalismo europeu viveu um refluxo nesse período, houve o ressurgimento do sindicalismo brasileiro, que se expandiu, aumentou em várias direções, realizou greves. As centrais sindicais nasceram nessa década de 80. A CUT já é, desde algum tempo, a central sindical com maior longevidade. No Brasil nós não temos experiências nem mesmo de centrais mais duradouras. Nos anos 90, a ação dos sindicatos e sua vitalidade dependem deles se vincularem mais solidamente com as lutas so-ciais e com os movimentos sociais.

Que movimentos sociais têm sido mais ousados no Brasil? Por que o Movimento dos Sem-Terra é tão combatido? Por que é ele o movimento mais importante da oposição do país atualmente? Porque foi mais ousado enquanto movimento social. Porque foi menos institucionalizado, porque é menos burocratizado, porque é mais contra a ordem, porque tem forte vínculo com as lutas sociais.

A questão do trabalho industrial é outro ponto muito interessante para discussão. Em trabalho recente foi afirmado que a divisão entre os setores industrial, agrícola e de serviços desapareceu. Hoje o problema seria muito mais complexo: haveria o terceirizado no setor industrial e o terceirizado no setor agrícola e no setor de serviços, que inclui os bancos, por exemplo. Assim, o produtivo que se tornou improdutivo e o improdutivo que se tornou produtivo se misturam. Quando falo sobre o trabalho, refiro-me ao cenário produtivo, mas não só ao industrial; penso nas interconexões que não eliminam a questão do trabalho, mas lhe dão amplitude, ainda que de maneira mais heterogênea, mais fragmentada.

Qual o desafio da classe trabalhadora? O que significa pertencer a uma classe hoje? O capital tem ganho essa batalha de fraturar as classes trabalhadoras e, no fundo, fazer com que o trabalhador se volte contra o próprio trabalhador, o nacional contra o imigrante, o homem contra a mulher, levando à exclusão do jovem e do velho. São muitas as tensões e, por isso mesmo, devem ser tratadas em seu conjunto. Mas o desafio primeiro dos trabalhadores é resgatar o sentido de pertencimento de classe, que o capital tenta destruir e que cabe ao mundo do trabalho resgatar.

Os processos de trabalho

Glauco Arbix (Unicamp) - Acredito que o problema não seja ter ou não nostalgia do fordismo, porque hoje se vive o taylorismo e o fordismo. As discussões sobre o toyotismo, as recomendações dentro do processo de trabalho, os novos processos de produção e de organização do trabalho são tendências no mundo inteiro, não só no Brasil. A indústria brasileira, o comércio e os serviços são fordistas, têm uma organização do trabalho absolutamente cruel, fragmentada, controlada. São raríssimos os trabalhadores que correspondem à idéia de alguém que fica sentado fazendo o que quer, no momento que quer, quando quer, sem controle, sem o reloginho de ponto, sem avaliacão de tempo e desenvolvimento.

Qual das empresas da Toyota, mesmo dentre aquelas que constituíam o chamado modelo toyotista, deixou de lado a discussão sobre tempo e desenvolvimento? Quanto ao trabalho de grupo, nas empresas Toyota, Nissan, Honda, qual delas teve uma experiência 
tão rica quanto a da Volvo, onde efetivamente se montou um grupo de trabalho com autonomia? Autonomia significa ter qualificação para exercer a autonomia. Em qual delas houve?

Questão bastante atual é a situação do sistema bancário brasileiro, que tem apresentado um grau de preparação e de qualificação extremamente elevado. O trabalho no sistema bancário no Brasil nunca foi tão taylorizado como está sendo hoje, com pessoas trabalhando diante de um computador monstruoso que controla absolutamente tudo o que elas fazem. Esse computador informa ao controlador cada sinal que o operador faz diante do monitor, quanto tempo levou, se foi ao banheiro ou não, se conversou ou não, quantas ligações fez, quantas operações fez, quando terminou. Pensando no mito que se criou em torno das novas tecnologias, seria preciso ter um trabalhador hiperqualificado, com qualificação muito maior para exercer sua função.

Evidentemente, existe uma série de processos que exige maior qualificação e as indústrias procuram trabalhar com uma força de trabalho mais qualificada. Elas são obrigadas a observar o sistema, as reformulações da organização do trabalho que estão sendo desenvolvidas. Na verdade, no mundo inteiro - e também no Brasil -, as formas de produção estão cada vez mais frágeis. O que isso quer dizer? Se um trabalho de just in time é montado, no qual se é obrigado a manter sistemática de entrega, hiperprogramação, hipercontrole, planejamento extremamente apurado, qualquer desequilíbrio no relógio estruturado pelo toyotismo significa a quebra do sistema montado. Na Fiat, em Betim, há entregas a cada 12 minutos devido à produção do automóvel Palio. Isso significa que a cada 12 minutos entra alguma mercadoria - vidro, pneu, roda. Seria desastrosa a ocorrência de uma greve, que comprometeria todo o sistema.

Nesse sentido, absolutamente todos os novos sistemas produtivos são frágeis. Não é à toa que a palavra mágica, pesquisada pelos construtores e pelas empresas hoje, é parceria. Por que a palavra é parceria? Por que há um trabalho conjunto? Porque há a preocupação em envolver o trabalhador, em combater o desestímulo dentro das empresas que o fordismo ou o taylorismo provocaram com o trabalho robotizado, desgastante. Por isso, discute-se, mas esse trabalho é, fundamentalmente, um trabalho de atrelações.

Assim, quem trabalha com a empresa tem de ter uma qualidade diferente, porque se não a tiver, o sistema não funciona. Esse não é um problema industrial, nasce na indústria mas se estende para todos os setores. Essa é a vitalidade da indústria automobilística, que revolucionou a forma de produzir no começo do século. Mesmo parecendo improvável, o conversor de vitalidade parou de fun-cionar, a organização da produção no final do século xx teve de ser modificada.

TRABALHO INDUSTRIAL - Em grandes corporações no Brasil há experiências que dão maior autonomia para o trabalhador dentro das fábricas, muito mais do que no setor de serviços. As experiências de vanguarda no que diz respeito à alta qualificação do trabalhador e à autonomia para ele estão sendo feitas hoje dentro da indústria, por mais paradoxal que pareça. Isto diz respeito às origens dos novos métodos disseminados pelo mundo inteiro e à natureza do trabalho realizado. Os maiores ciclos de trabalho atualmente no sistema estão na indústria, enquanto que no setor de serviços há redução do ciclo de trabalho ao mínimo possível.

Quem tem acesso a bancos por telefone sabe do que estou falando. Não se consegue ouvir o operador devido à rapidez com que fala. Ele fala rápido porque nasceu falando rápido? De forma alguma. Ele fala rápido porque tem um computador em seu ouvido, apitando. Aparece um sinal na tela, aparece o supervisor. Não é à toa que há uma brutal disseminação de doenças de trabalho no meio bancário e nos ambientes que trabalham com 
alta tecnologia, que atendem o público e prestam serviços. Isso está sendo controlado por tecnologia de alta capacidade.

Dessa forma, já estamos vivendo uma nova era. É o trabalho do futuro, uma tendência com a qual temos de conviver. Ninguém pode fechar os olhos e se esconder. Mas a realidade, às vezes, é bem diferente. Em 1996, estive na Mercedes Benz por quatro vezes e constatei que há setores novos, extremamente diferenciados, nos quais os trabalhadores definem o roteiro das peças etc. Mas $99 \%$ da fábrica é um verdadeiro desastre, e feliz de quem não trabalha lá. Para a grande maioria, ser operário foi e continua sendo um encargo extremamente pesado, não apenas na Mercedes. O trabalho industrial gera reclamações que o Brasil vai carregar por muito tempo. Entretanto, ainda oferece mão-de-obra disponível e possibilidades de remanejamento sem causar grandes problemas.

Quanto à questão da política industrial, é claro que o governo tem uma política industrial, ainda que não seja exatamente explicitada porque se tenta apresentar uma espécie de taylorização da análise. Taylor falava que existe apenas um caminho, the one best way. Há hoje uma operação científica do trabalho, em que se tem de produzir de determinada forma. Parece que há em curso a idéia de a tendência à globalização ser inevitável. Entretanto, acredito que a maneira pela qual nos integramos a essa globalização pode ser diferenciada. E não se trata de pensar em uma alternativa além do capitalismo. Trata-se, antes de tudo, de discutir dentro dos quadros do próprio capitalismo, por que outros países fizeram essa integração de maneira completamente diferente.

Anteriormente, Paulo Nogueira Batista Jr. levantou a seguinte questão: no Brasil, todos discutem questões do Primeiro Mundo que não são aplicadas lá, e isso é real. Discutese sobre as câmaras setoriais como sendo resquício de um velho período, um protecionismo que está sendo abandonado. Mas em qual país do mundo há livre mercado? O que se viu no setor industrial, em particular na indústria automobilística dos Estados Unidos, quando o Japão tomou conta do mercado americano nos anos 80? O próprio presidente George Bush foi ao Japão, escoltado pelos três principais fabricantes de automóveis - Ford, General Motors e Chrysler -, para solicitar gentilmente ao governo japonês cotas voluntárias para exportação. Pediram que o governo japonês limitasse o número de veículos a serem transportados para os Estados Unidos e passasse a produzir diretamente lá.

No Brasil, não temos como prática colocar restrições, barreiras alfandegárias ou aumentos de alíquotas. Recentemente, o governo Clinton reuniu diversos institutos de pesquisa ligados às Forças Armadas norte-americanas. Com o fim da Guerra Fria, vários desses institutos de pesquisa - da Nasa, da Marinha, dos Fuzileiros Navais - viram-se em situação delicada, sem ter o que produzir. Assim, o governo Clinton criou uma câmara setorial que reuniu tais institutos para trabalhar em conjunto com Chrysler, Ford e General Motors objetivando produzir um motor para o ano de 2005 que tenha um índice de altíssimo nível, não seja poluente etc. É estranho que um governo liberal quanto ao comércio internacional nas importações e exportações crie um mecanismo desse tipo. No Brasil, isso raramente acontece. Se por um lado a política industrial brasileira incentivou as grandes empresas nunca houve na história do país tanto apoio às montadoras -, por outro fragilizou o setor de autopeças, que hoje está às vésperas de um colapso.

\section{A estratégia dos sindicatos}

Sergio Mendonça (Dieese) - Vindo da área sindical, como eu venho, acho que muitas das intervenções aqui apresentadas atribuem aos sindicatos responsabilidade muito maior do que a que eles têm. Algumas intervenções exigem dos sindicatos, eventualmente, a resolução de todos os problemas do país. Isso é impossível, já que o movimento sindical nasce com uma característica específica: representar determinados interesses. 
Quando foi mencionado que se trata de decidir se os sindicatos estão mais ou menos contra ou favor da ordem, ou ao se questionar qual sua lógica, diria que brigar para gerar empregos é algo que vai radicalmente contra a lógica, porque a lógica é não criar empregos. O capital segue numa linha de investimento em inovações tecnológicas e cada vez menos trabalho humano. Se os sindicatos conseguem empreender, com toda a sociedade, uma luta pela existência de empregos, diria que eles são contra a lógica, estão questionando a inevitabilidade do sistema vigente.

Concordo plenamente não ser possível que a humanidade caminhe para considerar virtuoso o modelo que produz cada vez mais desigualdade e mais desemprego. É impossível imaginar que esse modelo seja virtuoso em escala mais global. O Movimento dos SemTerra, que sem dúvida alguma se destaca atualmente como o movimento de maior oposição à lógica vigente, está discutindo o quê? Está discutindo a reforma agrária, uma das mais antigas questões da política brasileira e mundial. E o que faz o Movimento dos Sem-Terra? Faz uma ação para a negociação. A lógica do Movimento dos Sem-Terra é muito clara, profissional e competente. Uma ação, uma invasão, uma negociação e um recuo; outra ação, outra invasão, outra negociação e outro recuo.

Se o movimento sindical, tendo que discutir empregos, tem de entrar na discussão da lógica das empresas, talvez esse seja o alto preço a ser pago para o futuro, o preço da cooperação. Ou seja, o movimento sindical que discute o emprego não é necessariamente o movimento sindical das décadas de 70 e 80 , que cresceu porque lutava também pela democratização do país, apresentava uma discussão que ia além da questão salarial, uma discussão mais geral da socie-dade. Pode até ser difícil combinar a tentativa de não gerar novos empregos, que é a lógica do sistema, com a necessidade da geração de empregos, que não faz parte da lógica do sistema. Nesse sentido, a questão do Movimento dos Sem-Terra é elucidativa. O Movimento está negociando algo antigo mas que, apesar disso, no Brasil, é contra a lógica do sistema, por tratar da reforma agrária. E só se afirma porque é capaz de negociar.

Se o movimento sindical brasileiro representa apenas 20 ou $25 \%$ da classe trabalhadora, que estes $20 \%$ estejam bem representados na negociação de seus interesses. Além disso, o movimento sindical deve conseguir tratar questões mais abrangentes, relacionadas ao contexto sócio-político-econômico, como fez nas décadas de 70 e 80 com relação à discussão sobre a democratização do país. Assim, a discussão sobre empregos pode ser vista como algo arcaico, porque é absolutamente contra a lógica, porque qualquer economista, qualquer analista, qualquer teórico sabe que a tendência é não criar novos empregos. Não há nada acontecendo no mundo que seja relativo à geração de empregos quando se pensa em reestruturação. Portanto, ao fazer isso, os sindicatos estão indo contra a lógica dominante.

JOVENS TRABALHADORES - Há, ainda, algumas contradições que merecem ser registradas. O Japão, que de alguma forma tem desequilibrado o jogo global nos últimos 20 anos, vai passar por movimentos difíceis e contraditórios, como foi apontado no texto de Jacob Gorender.

Um deles é que a classe trabalhadora jovem não está mais disposta, em princípio, a atuar da mesma forma que os trabalhadores japoneses têm atuado nos últimos 40 ou 50 anos. Os mais velhos tendem a ver os jovens como rebeldes, mas acreditam que sua adequação ao sistema seja só uma questão de tempo. Há quem diga isso. Mas sabe-se que há uma resistência enorme dos trabalhadores japoneses jovens a entrar nesse ritmo. A própria Toyota, como já foi aqui mencionado, montou uma fábrica no norte do Japão com um ritmo de trabalho diferente, por pressão da sociedade japonesa: uma fábrica que trabalha em ritmo mais lento se comparada a outras fábricas da mesma empresa. A linha de produção é inferior às outras tantas da Toyota e isso só ocorreu devido, como mencionado, à pressão da sociedade japonesa. 
As mulheres, no Japão, que já somam $37 \%$ da força de trabalho e sempre foram a variável de ajuste do mercado nos momentos de pico, não estão necessariamente dispostas a continuar dessa forma, já que estão efetivamente avançando em sua capacidade de representação perante a sociedade japonesa.

Contraditoriamente a tudo o que está sendo discutido sobre as relações de trabalho e o papel mais ou menos forte dos sindicatos, vê-se na França - onde o sindicalismo mais caiu nas décadas de 80 e 90, representando hoje entre 5 e $7 \%$ da força de trabalho - um processo de resistência às mudanças desenvolvido pelos estudantes e por ação de outros grupos organizados. Ou seja, não é que os sindicatos estejam fadados ao desaparecimento; mas é preciso haver certa compreensão da dimensão do seu papel. Os sindicatos devem ser vistos apenas como mais um dos atores desse processo, e não se deve pensar que conseguirão, sozinhos, empreender uma batalha no sentido de ir contra a lógica do sistema.

Mesmo na Alemanha, onde o sindicalismo sempre foi mais combativo que cooperativo, buscou-se o aprofundamento da cooperação, mas sem muito êxito, sem encontrar eco no empresariado alemão. Nesse momento, sindicatos e empresariado estão em vias de rompimento. Vemos um sindicalismo que já foi forte e tratou de usar a estratégia da cooperação para avançar, mas que atualmente não consegue avançar. Essas contradições colocam diversas indagações, apontando não haver qualquer modelo em curso que seja claro e evidente, e que tais questões precisam ser melhor analisadas, pois provavelmente, ainda que não em curtíssimo prazo, implicarão mudanças na lógica da globalização.

\section{O envolvimento da sociedade}

Representante da Comissão de Fábrica da Volkswagen - Como trabalhadores, estamos vivendo esse momento da globalização com bastante impacto. A discussão sobre a terceirização, por exemplo, é muito difícil. Concordo plenamente com a idéia de que todos devem ser responsabilizados e envolvidos nessas discussões sobre as relações de trabalho, e não apenas o movimento sindical. A responsabilidade não deve ser atribuída apenas aos sindicatos, como diversas vezes foi aventado aqui. É preciso envolver a sociedade como um todo. Não ouvi alguém dizer, por exemplo, qual é o papel dos partidos políticos nessa discussão. Ninguém apontou a questão.

Na década de 80, enfrentávamos o militarismo, e eu afirmo que era mais fácil enfrentar o militarismo do que a revolução que está acontecendo hoje dentro das fábricas. Mas naquele tempo havia também o movimento partidário participando, as entidades de classe, a sociedade civil, a $\mathrm{OAB}$, a Igreja, enfim, havia várias entidades que estavam dentro do movimento e ajudavam os sindicatos a combater o militarismo, a fazer essa mudança social que hoje persiste. Gostaria que a discussão voltasse a ser colocada nesse nível. Aliás, minha visão é que, se não voltar a esse nível, realmente vai ser muito difícil para nós, sindicalistas, conduzir qualquer reação dentro das empresas.

A discussão que fazemos dentro das fábricas é um pouco diferente dos assuntos tratados aqui. Hoje discute-se, por exemplo, a questão dos planos médicos, da terceirização etc., e em todas estas discussões a comissão de fábrica e a diretoria do sindicato estão presentes. Ficamos um pouco isolados dentro das fábricas, distanciados de discussões como as que aconteceram aqui.

Certo dia encontrei alunos de uma universidade na fábrica, pesquisando, envolvidos, ou seja, querendo encontrar saídas junto com os trabalhadores: isso é muito importante. Mais pessoas precisariam estar envolvidas nesse papel para nos ajudar a encontrar saídas, porque enquanto só o movimento sindical estiver sendo responsabilizado para reagir quanto às questões aqui propostas, será muito difícil encontrar soluções. 


\section{A questão da propriedade}

Carlos (PUC-SP) - De todos os debates que presenciei, fica uma reflexão muito dura do ponto de vista das classes trabalhadoras: os intelectuais coletam uma série de dados da realidade, fazem constatações, analisam os dados e não colocam saídas que extrapolem o marco destas constatações. Percebe-se que vivemos, na realidade, um processo de acumulação do capitalismo; discute-se o tema sob vários ângulos, mas parece que todos ficam em estado de imobilidade. Não ouvi neste debate referência alguma à problemática da propriedade, por exemplo. Articula-se ou tenta-se articular pelas palavras, pelos discursos, para induzir ideologicamente. O movimento sindical trata da discussão sobre emprego, desemprego, precarização das condições de trabalho, câmaras setoriais, posição do Estado, do bem-estar com relação às políticas públicas - todas as discussões colocadas no marco do capitalismo - e em nenhum momento tratou da questão das propriedades. Como isso acontece? Parece que a questão não tem sido mais discutida pelo movimento sindical e pela classe trabalhadora em geral.

\section{Emprego e trabalho}

João Caio (CIPA-Ford) - Gostaria de colocar a questão do emprego e do trabalho. Falou-se muito na empregabilidade, mas e a questão do trabalho? Existem alguns teóricos afirmando que no futuro não vai existir emprego, mas trabalho. O que se pode esclarecer sobre isso? Outra questão é que no ABC está acontecendo um problema muito grave quanto aos salários. A Fiat, por exemplo, paga aos trabalhadores metade do salário das montadoras aqui do ABC. Outras empresas do interior de São Paulo também pagam salários menores, e ainda avaliam que o trabalhador do interior tem melhor qualidade de vida que o trabalhador do $\mathrm{ABC}$, pois não enfrenta esse trânsito enorme, por exemplo. Apesar do trabalhador do $\mathrm{ABC}$ ganhar melhor, ele vive pior, por significativa parte morar em favelas, não ter casa própria.

O problema que vem acontecendo é as empresas estarem jogando bem claro com os sindicatos ao afirmar que não irão propor redução de salários - porque sabem que os sindicatos não vão aceitar - mas irão embora, porque em lugares com menores salários e mais qualidade de vida para os trabalhadores será mais fácil trabalhar.

Outra questão importante refere-se à guerra fiscal. O estado do Paraná, por exemplo, vai entrar com $30 \%$ para construir a fábrica da Renault. Em São Carlos, só faltou o município edificar a fábrica para a Volkswagen. Na verdade, as empresas estão se tornando uma franquia, como acontece em Resende. O estado do Rio propicia todas as vantagens, e apenas 300 empregos são gerados. Assim, uma questão que podemos discutir claramente é a da ousadia dos sindicatos. Ouve-se falar muito em ousadia, e eu quero colocar o exemplo da fábrica onde trabalho. A empresa aposta muito na questão da globalização. Como? Os carros médios, que eram feitos aqui, foram transferidos para a Argentina; o Brasil vai fabricar apenas um modelo de carro. Essa estratégia é diferente daquela adotada pela Fiat, GM e Volkswagem, que produzem carros grandes aqui no Brasil.

A empresa reclamou muito dos custos e de outros fatores com relação às outras montadoras, apresentando inclusive uma proposta de flexibilização da jornada de trabalho, em princípio aprovada, que variava entre 38 e 44 horas. Depois, quis flexibilizar além disso, de 38 a 45 horas, proposta rejeitada pelos trabalhadores, o que gerou um impasse interno. A empresa sinaliza que não pode mais trabalhar com o sindicato, sinaliza até em acabar com o relacionamento com a representação sindical, um pouco na linha do que ocorreu na Mercedes.

A Ford promoveu uma grande discussão sobre o assunto, avançou bastante, implantou o trabalho em grupo entre outras coisas, e hoje sinaliza com outra alternativa: ou se negocia certas coisas que já foram conquistadas ou o relacionamento estabelecido estará 
sendo colocado em risco. O impasse é muito grande e o movimento sindical deve enfrentálo. Nesse sentido, as microempresas, por exemplo, vivenciam realidade diferente. Para as grandes empresas, não existe realmente uma política industrial por parte do governo.

\section{Organização sindical}

Um dos presentes - Quanto à questão da liberdade e da autonomia sindical, cabem algumas considerações. Por que, hoje, algumas empresas, dentro das quais os trabalhadores já haviam alcançado determinado grau de organização no local de trabalho, se atrevem a colocar em xeque essa organização? Por uma razão muito simples. Porque elas contam com o apoio do Estado, e a intervenção do Estado que ainda se realiza junto ao movimento sindical, para assim proceder. Se houvesse liberdade sindical, autonomia e o direito de organização, essa organização não estaria em questão. Não se discutiria apenas se a empresa vai ou não vai escalar determinada pessoa para atividades sindicais, mas que tipo de sindicato deveria existir. Não haveria um sindicato dos metalúrgicos do $\mathrm{ABC}$, mas um sindicato dos metalúrgicos do estado de São Paulo, e aí, a negociação dar-se-ia em outro patamar.

É preciso refletir sobre essas questões, não apenas nos sindicatos, mas sobretudo, além deles, nas diversas esferas da organização sindical. Não é apenas na organização sindical que a questão de classes aparece, mas muitas vezes ela aí se expressa com muito mais força porque no chão da fábrica, no local de trabalho, a questão da exploração está colocada com muita veemência. Para nós, está cada vez mais claro que o sindicato deve ir além das fronteiras das categorias. Mais do que isso, porém, ir além dos limites que lhe foram impostos por uma organização sindical, como se tivéssemos tido, no Brasil, um movimento sindical fortíssimo ao longo de décadas, quando o exemplo é exatamente o contrário. O movimento sindical brasileiro só foi estruturado com mais força e organização a partir da década de 80 . Não é que não tenha havido história sindical alguma antes disso; houve sim, e importante. Não queremos ser responsabilizados por certas coisas, mas não abrimos mão da responsabilidade de ajudar a construir uma sociedade nova.

\section{Palavras finais}

Jacob Gorender (IEA-USP) - Muitas questões poderiam ser abordadas neste momento, mas apenas algumas serão tratadas por parecerem mais necessárias. A riqueza de aspectos que envolvem os temas do debate é imensa, mas a questão do custo de trabalho merece ser destacada. Seguindo a linha do sociólogo espanhol Manuel Castells, o custo de trabalho não é significativo para a competitividade de uma economia.

Obviamente, é significativo para o empresário, tal constatação é elementar; o empresário vai preferir sempre um trabalho mais barato, e nem se pode condená-lo por isso, não há por quê. Se ele pode encontrar, dentro de condições convenientes (proximidade, e assim por diante), um trabalho mais barato, irá atrás desse trabalho. As multinacionais têm enorme mobilidade, podem sair rapidamente do Brasil e ir para o Extremo Oriente, ou para outro ponto qualquer do planeta. Portanto, terão mais facilidade para dispor de trabalho barato.

Mas a questão que deve ser colocada é a seguinte: o tênis Nike, fabricado no Extremo Oriente, é na verdade projetado e desenvolvido nos Estados Unidos. Não é por terem um trabalho mais barato que os países nos quais se fabrica o tênis Nike são mais competitivos. $\mathrm{O}$ que torna uma economia realmente competitiva são os fatores sistêmicos, dentro dos quais está inserido o próprio custo de trabalho. É evidente que o custo de trabalho não pode ser arbitrário, ninguém pode pensar que, se o custo de trabalho duplicar de hoje para amanhã, seja no Brasil, na Alemanha ou na Suécia, a economia suportará essa duplicação de um dia para o outro. Isso está fora de questão. 
O custo de trabalho é o resultado da correlação de forças de classe, da história da economia e de uma série de outras circunstâncias em determinado momento. Ele pode ser alterado, mas não pode ser alterado arbitrariamente sem dano para a própria economia. Entretanto, uma economia competitiva não é necessariamente uma economia de trabalho barato. Se fosse assim, as economias alemã, norte-americana, japonesa, sueca já estariam comprometidas há muito tempo, e a economia mais competitiva seria a dos países da África negra ou de Bangladesh. Não é isso que ocorre, de maneira alguma.

TRABALHO FEMININO E INFANTIL - Outras questões aqui colocadas que, infelizmente, não puderam ser desenvolvidas são as do trabalho feminino e do trabalho infantil. Essas são questões que têm muita importância para o emprego. O fato do trabalho feminino ser rebaixado, ser mais barato - em regra, é isso o que acontece - faz com que, é claro, as empresas preencham uma série de cargos com mulheres. No Japão, país tão citado, de acordo com Helena Hirata, uma brasileira com sobrenome japonês, as trabalhadoras que ocupam postos na indústria automobilística e em outras indústrias são, em geral, mulheres com mais de 40 anos. Por quê? Porque elas já não apresentam mais o risco de serem fecundas, de ficarem grávidas. Daí que as empresas nipônicas prefiram trabalhadoras na faixa etária mais avançada, acima dos 40 anos. Este é apenas um dos pontos extremos a que a questão da exploração do trabalho feminino pode chegar. Tal trabalho é, em geral, o mais precário, o mais temporário e o mais afetado pelas oscilações conjunturais.

O trabalho infantil é outro grande problema. Há uma cifra citada de que existem 7 milhões ou 7,5 milhões de crianças e adolescentes explorados de maneira estafante aqui no Brasil. Não se pode afirmar ser tal cifra exata, mas o fato é que há uma quantidade muito grande de crianças trabalhando, e essa questão apenas começa a aflorar. Algumas prefeituras estão beneficiando famílias de baixa e baixíssima renda com um subsídio, acompanhado da exigência de que os seus filhos, em vez de trabalharem, sejam encaminhados para as escolas e ali adquiram instrução. Mas isso é apenas um começo, um arranhão desse gravíssimo problema, ou seja, há várias questões gravíssimas que dizem respeito ao desemprego, como o trabalho feminino mais explorado, ou o trabalho infantil, e até o trabalho do tipo escravo também verificado no Brasil.

Eliminar as formas perversas de trabalho certamente deverá diminuir consideravelmente as cifras do desemprego.

PERSPECTIVAS - A questão do desemprego não se restringe somente ao fato de a indústria estar se retraindo enquanto tal. O contingente de trabalhadores industriais diminui também porque vários trabalhos, várias tarefas, vários setores que antes eram incorporados à indústria estão hoje terceirizados, foram transferidos ao setor de serviços. Ainda há pouco, ouvimos que a Volkswagem vai terceirizar o setor de recursos humanos, entregando o treinamento de seus trabalhadores a empresas externas, as quais serão computadas como serviços. O setor de transportes também está sendo terceirizado, ou seja, muita coisa sai do setor industrial e vai para um setor externo, é terceirizada. Nem por isso, muda a natureza da tarefa, agora executada fora da empresa.

Com isso, é claro que a estatística faz com que o setor de serviços se engrandeça e o industrial se torne menor, menos significativo. Mas para a economia, que diferença faz? Para a economia como um todo, não faz diferença alguma. O que parece é que a estatística convencional da época do fordismo está ultrapassada. Hoje, a questão de serviços, indústria e agricultura está muito modificada. Faz-se necessário considerar itens estatísticos bem diferentes dos atuais, que dividem o trabalho em intelectual, manual e assim por diante.

Um aspecto merece ser destacado. Mesmo com toda a tecnologia dos anos 70 para cá, com essa revolução tecnológica tão comentada, o que está acontecendo? Com toda essa 
tecnologia, não só a produção é medíocre, as taxas de crescimento são medíocres - inferiores à época dos 30 anos imediatamente posteriores à Segunda Guerra Mundial -, como o aumento da produtividade também é fraco. Mas como é isso possível?

Com tantos computadores, com tanta biotecnologia, novos materiais, telecomunicações instantâneas e tudo o mais, ainda assim a produtividade aumenta vagarosamente, pelo menos mais devagar do que antes. O que está acontecendo? Não quero aqui propor qualquer explicação cabal, mas é um ponto de interrogação, indicando que alguma coisa não está funcionando bem, ou não funciona favoravelmente àqueles que estão empregados e àqueles que estão desempregados. Talvez, para algumas empresas, tudo isso esteja muito bem, mas não para a grande maioria da sociedade, para aqueles que vivem do trabalho.

O fato é que tal preocupação se manifestou aqui, e se não reagirmos a essa situação, todos aqueles que têm necessidade de reagir - e não se trata aqui de voluntarismo, de quixotismo, mas da necessidade de defesa mesmo -, aonde iremos parar? Pelo menos o quadro que se desenha é aquele que Robert Reich, secretário do trabalho do governo Clinton - autor do livro O trabalho das nações, escrito antes de que ele ocupasse tal cargo - prefigura: a formação de uma sociedade profundamente seccionada, uma sociedade realmente cindida em duas partes. Podemos imaginar o que vai acontecer diante dos condomínios fechados com seus muros muito altos. Uma parte está superprotegida e a outra, a imensa maioria da sociedade, está abandonada a sua própria sorte, sujeita aos assaltos, ao banditismo. Inclusive, ao pior dos banditismos, que é o desemprego e a fome. Este é o quadro que se desenha.

Segundo Reich, a sociedade em gestação terá $20 \%$ que viverão da propriedade, serão muito ricos e terão também empregos muito bons, de natureza intelectual, que lidam com símbolos. Serão homens e mulheres que trabalharão em laboratórios, no marketing, nas finanças, enfim, que estarão muito bem colocados. Cerca de $30 \%$ das pessoas farão o trabalho repetitivo das fábricas, continuarão obrigados a isso, ao trabalho estafante e degradante, descrito aqui por Glauco Arbix. Farão ainda o trabalho do setor de serviços: garçons, enfermeiros, motoristas de taxi, todo tipo de serviços pessoais, sendo este um setor que deve crescer, porque os ricos querem mais serviços, mais gente para atender às suas necessidade. Aí temos metade da sociedade. A outra metade da população viverá da assistência pública, precisará do cheque que o Estado lhe puder fornecer, e se o Estado não puder fornecê-lo, povoará as ruas realizando os chamados bicos, com todos os tipos de variações.

Mas o autor, no final de seu livro, propõe algumas alternativas para melhorar o quadro tétrico. Apela, sobretudo, para o espírito de solidariedade daqueles que estão bem de vida. Tais apelos entretanto serão inócuos e dificilmente terão sequer pequenos resultados.

Sem querer oferecer aqui qualquer receita, porque eu não tenho essa receita, acredito, com o que hoje ouvimos, podermos pelo menos trabalhar no sentido prático. O fundamental realmente é que sindicatos, trabalhadores, profissionais liberais, engenheiros - que perderão seus empregos -, economistas - que também encontrarão dificuldades para se empregar ou perderão empregos -, todo o tipo de profissionais, incluindo aqueles que esta universidade gradua e pós-gradua, que todos nós que estamos no mesmo barco, saibamos dirigi-lo. Se não soubermos dirigir o barco a um porto bonançoso, exercitaremos a solidariedade dos náufragos.

\section{Notas}

1 Organization for Economic Co-operation and Development. OECD Economic Outlook 57. Paris, June 1995, p. A31; OECD Economic Outlook 59. Paris, June 1996, p. A31. 
2 Id. Ib., 1995, p. A32; 1996, p. A32.

3 Id. Ib., 1995, p. A37-38; 1996, p. A37-38.

4 International Monetary Fund. World Economic Outlook, May 1996, p.45.

$5 I d . I b ., \mathrm{p} .45-46$.

6 The Economist, Sept. 30th 1995, p.122.

7 Dados reproduzidos por P. Hirst \& G. Thompson, 1996, p.96-97.

8 A estimativa baseia-se em dados referentes a companhias dos Estados Unidos, da Europa Ocidental e do Japão. $I d$. Ib., p.97-98.

9 M. Laplane, O complexo eletrônico na retomada do crescimento industrial dos anos 80 nos paises desenvolvidos. Campinas-SP, 1992, tese (doutoramento). Instituto de Economia da Unicamp; L. Coutinho, A terceira revolução industrial e tecnológica. In: Economia e Sociedade, n. 1, Campinas, Instituto de Economia da Unicamp, ago. 1992.

10 Fábio Erber, Paradigma tecnológico, complexo industrial e política econômica da microeletrônica. XIII Encontro Nacional de Economia, Anais. Anpec, v.2, Vitória, 1985.

11 J.A. Schumpeter, A teoria do desenvolvimento econômico, São Paulo, abr., 1982.

12 Coutinho, op. cit., nota no 13, p.70-71.

13 Freeman \& Peres, op. cit., nota $n^{\circ} 19, \mathrm{p} .23$.

14 Coutinho, op. cit., nota $\mathrm{n}^{\mathrm{o}} 13, \mathrm{p} .74$.

15 C. Pérez, Cambio técnico, reestructuracion competitiva y reforma institucional en los paises en desarrollo. Discussion Paper n. 4, Banco Mundial, 1989, p.21.

Referências bibliográficas

EICHENGREEN, Barry. International monetary arrangements for the 21st century. Washington, D.C., The Brookings Institution, 1994.

FERRO, Marc. História das colonizações: das conquistas às independências, séculos XIII a XX. São Paulo, Schwarcz, 1996.

GORENDER, Jacob. Globalização, revolução tecnológica e relações de trabalho. Série Assuntos Internacionais - 47, Instituto de Estudos Avançados, Universidade de São Paulo, set. 1996 [mimeo].

HIRST, Paul \& THOMPSON, Grahame. Globalization in question: the international economy and the possibilities of governance. Cambridge, U.K. Polity Press, 1996.

PATEL, Pari \& PAVITT, Keith. Large firms in the production of the world's technology: an important case of "non-globalization". Journal of International Business Studies, v.22, n. 1, First Quarter 1991.

WADE, Robert. Globalization and its limits: reports of the death of the national economy are greatly exaggerated. In: Suzanne Berger \& Ronald Dore (eds.), National diversity and global capitalism. Ithaca, New York, Cornell University Press, 1996. 